\title{
ע ARTISTS AND SOCIETY IN MODERN TIBETAN LITERATURE
}

\author{
Riika J. Virtanen \\ University of Helsinki
}

\begin{abstract}
It is usually thought that modern forms of Tibetan culture started to emerge largely in the latter half of the twentieth century, although there existed some signs and developments of modernization already in the first half. Since then, modern and traditional arts have existed side by side, often influencing each other and even appearing in hybrid forms. This situation is reflected in stories about artists in contemporary Tibetan fiction: these literary works include stories about artists which reflect both traditional Tibetan arts and folk culture and modern arts. This essay focuses on prose works by three writers: Dhondup Gyal (1953-1985), Tashi Palden (b. 1962), and Tsering Dhondup (b. 1961). In the works discussed, the main characters are representatives of different art forms. The stories contain descriptions of the lives of artists and themes related to becoming, practising, and living as an artist. After the occupation of Tibet by the People's Liberation Army of the People's Republic of China in the 1950s, Tibetan society underwent a considerable transformation. The changes in society and its norms and values are also reflected in the descriptions of the artists' lives. The relationship between artists and the surrounding society cannot be characterized unidimensionally. The stories describe highly differing attitudes and values towards culture and art, which range from appreciating and being supportive to limiting and being negative. The relationship between the artist and society may also undergo changes within a single story, reflecting the influence of different attitudes and cultural policies in the society towards the practice of an artistic vocation. Examining the descriptions of artists and the theme of living as an artist, this essay contributes to the discussion of the genre of artist stories in Tibetan culture.
\end{abstract}

\section{INTRODUCTION}

In this essay I shall discuss four artist stories authored by three different writers in Tibetan. ${ }^{1}$ Two of them are short stories authored by Dhondup Gyal (Don grub rgyal), and the other two are a

\footnotetext{
1 This essay is based on my presentation at the conference "Himalayas and Beyond: Cultural, Religious and Social Research in Tibet, Bhutan, Nepal and Amdo", 25 September 2012 at the University of Helsinki. I am grateful to the Kone Foundation for supporting my research and the writing of this essay. I would also like to thank Franz Xaver Erhard and Thupten K. Rikey for reading a version of this essay and making many helpful comments. This essay was reshaped and benefitted greatly from the comments and suggestions made by the two anonymous reviewers, whom I also wish to thank. Since it took an unexpectedly long while to find time to make all the revisions to this article, I have also added some updates, including some references to new research that has emerged in the meantime. However, as the article was originally written several years earlier, these new references have mostly been included as short mentions in the footnotes. I also wish to thank Dr Albion M. Butters for revising the English language of this article. All the mistakes are, of course, my own.
}

Volume 8(1) (2020), pp. 85-119

DOI $10.23993 /$ store. 8662

Licensed under Creative Commons Attribution 3.0 License.

ISSN: 2323-5209

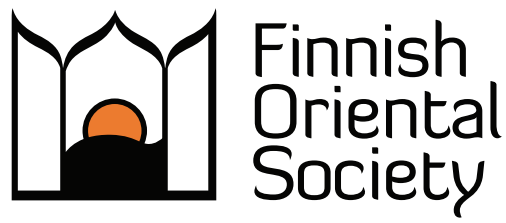


novella by Tashi Palden (bKra shis dpal ldan) and a novel by Tsering Dhondup (Tshe ring don grub). All these works have an artist as the protagonist or one of the main characters, and this is the main reason why they are discussed together. The characters are artists from different fields of art, and the stories also depict artists of either traditional arts and folk culture or modern arts.

Although the expressions "traditional" and "modern" are used to convey a general idea about the art and artistic activities of the characters in the works, it is not meant that these two are completely isolated or disconnected phenomena. Although it is usually thought that the various fields of modern Tibetan culture developed during the second half of the twentieth century, it has been shown by various scholars that there were signs, as well as cultural and other kinds of developments, that can be interpreted as indicating the start of the modernizing of Tibetan culture already in the first half of the twentieth century, and even earlier. ${ }^{2}$ There are Tibetan artists who combine both traditional and modern techniques or elements in their works. ${ }^{3}$ By traditional arts, I generally just refer to art forms and styles that existed in Tibet already before its occupation by the Chinese and the larger-scale arrival of modernity in the twentieth century, such as thangka painting; I do not mean that they have been untouched by time and change.

When examining the artist stories, I see how the artists have been described, how their development and living and practising as an artist are depicted, and what kinds of relations between the artist and society are portrayed. I show that there are highly different attitudes towards artists and art and that the status and appreciation of an artist may undergo dramatic changes. I shall also present some remarks about whether it is feasible to speak about the genre of artist stories in Tibetan culture and how Tibetan artist stories differ from or resemble Western works in the genre. In order to gain some understanding of Western artists' stories and the ideas related to them, I have made use of Maurice Beebe's book on artist stories, Ivory Towers and Sacred Founts, which contains a discussion on several Western works and theoretical observations on typical features of artist characters and the genre. As expressed in the title of his work, Beebe (1964: vi, 13) has suggested the existence of two traditions of artist stories, which he respectively calls the Sacred Fount and the Ivory Tower. It is interesting to compare these ideas about artists to the artist char-

\footnotetext{
2 See Hartley 2008: 3-14; Engelhardt 2011; Heimsath 2005: 2; Morcom 2007: 1; Lopez 2013: 58. Among these early signs of modernizing Tibetan culture are included by scholars the literary and artistic works of Gendun Choephel (dGe 'dun chos 'phel) and the establishing of the first Tibetan newspaper. Gendun Choephel's literary works contain some features which can be thought of as modern, such as, for example, content demonstrating new ways of thinking and, as described well by Hartley, a tendency of vernacularization of the literary expression (Hartley 2008: 4-10; Lopez 2013: 32-39, 57-70). Also a painter, he played a role in the development of contemporary Tibetan art (Heimsath 2005: 2; Lopez 2013: 39). For information about the Tibetan newspaper Yul phyogs so so'i gsar 'gyur me long, which appeared in Kalimpong and was edited by Tharchin Babu (mThar phyin sba bu), see Engelhardt 2011: 206-213; Shakya 2004: 17-22; Lopez 2013: 40.

3 See, for instance, Harris 1999: 50-55, which contains a discussion and photos of the art of Jampa Tseten, a Tibetan thangka painter. As can be understood from Harris's discussion of the images and also by viewing them, even though the paintings are largely realist, it is possible to notice some details which owe to Tibetan traditional art and its motifs. Another example of a Tibetan painter in whose paintings both traditional and modern elements can be seen is Gade, whose art has been discussed by Leigh Miller $(2012 ; 2016)$. The mixture of traditional and modern elements is very evident here, especially in his works that include elements from Western culture, such as, for example, the "Mickey Mural". For a discussion of this painting, see Miller 2016: 65-67. Several examples of paintings by Tibetan artists, which combine both traditional and modern elements, can be seen in the catalogue of a Tibetan contemporary art exhibition curated by Lisa Tamiris Becker and Tamar Victoria Scoggin (2007). The exhibition took place at the CU Art Museum in 2006. If we consider the poetry of Dhondup Gyal (Don grub rgyal), who is considered an important figure for the development of modern Tibetan literature, some of his poems nonetheless make use of the traditional style of verse composition, although the content or topic is usually related with more modern times (see, for example, Virtanen 2014: 91-94, 129-132, 281-289).
} 
acters in Tibetan works. One of the main differences appears to be that the Tibetan works depict the process of becoming an artist from a partially different perspective, often stressing the idea of learning a profession instead of the idea of having a "calling" to become an artist, which seems more typical of Western conceptions about choosing the métier.

A large part of modern Tibetan prose works are written in a style that could be characterized as realistic, since they seem to depict the life of Tibetans in their usual environments and appear to attempt to create a life-like impression. However, when speaking about a style being realistic, it has to be kept in mind at the same time that what is written and can be published is also restricted and guided by ideas and attitudes connected to art in a society under Communist rule. In his book The Uses of Literature, Perry Link (2000: 56-68) has explained that in China it was usual to talk about "the weather" when speaking about control over literature, which changed from time to time and also depended considerably on the content of the speeches of political leaders. He names Mao's Talks at the Yenan Forum on Literature and Art as an important source for understanding the function of literature in China ${ }^{4}$ In this talk, a connection is suggested between art and society: the function of art is "to serve the masses of the people" (Mao Tse-Tung 1962: 12).

It is difficult to find any exact, clear-cut guidelines about what kind of writing is not acceptable to publish in the People's Republic of China (PRC). ${ }^{5}$ Tsering Shakya has written about the nature of the restrictions and control on literature in Tibetan society under the rule of the PRC. He describes it as a "system of checks and balances", which appears difficult to define as it may work on different levels. He insightfully points out how the authors need to be aware about the political climate and what kinds of publications can be accepted for publication, and then practise some "self-restraint". He writes about the selection process of contributions to a Tibetan literary journal where the final decision is made by an officer of the Communist Party. He describes the restrictions and guidelines regarding the content of literature: "In Tibetan areas the content needs to be faithful to the Party's goals, must not favor Tibetan nationalism and should oppose religion" (Shakya 2004: 113-116). It can be easily understood that in this kind of literary climate, which tries to guide and restrict the content of literary works, it is difficult for writers to express any opposing views. It depends on the individual writers themselves how much they wish to conform to politically accepted views, but certainly courage is needed to challenge such norms. Also, it is difficult to get published if the writings have content which does not conform. However, this does not mean that there are not unique ideas and works with ambiguous content, which can be interpreted in several ways. Furthermore, it may happen that a book is first published but then gets banned, as happened, for example, with Xizang Biji ("Notes on Tibet"), an essay collection written in Chinese by Weise, also known as Tsering Woeser (Tshe ring 'od zer). ${ }^{6}$

\footnotetext{
4 See also Yangdon Dhondup (2008: 39) for information on Mao's talks at Yan'an. She suggests that the period of the greatest influence of the views presented in the talks in question were in the decades prior to the 1980s.

5 Recently, Kamila Hladíková's article "Literary censorship and self-censorship in China" has appeared. According to the English language abstract of her article (written in Czech), censorship is viewed in the PRC as a "natural part of the Chinese literary system" (Hladíková 2018: 71).

6 See Yangdon Dhondup 2008: 32, 57, n. 2; Barnett 2013: xxvi.
} 


\section{THE ARTIST STORIES}

First, I shall introduce the literary works with artist characters. Two of the stories appeared in the 1980s and were authored by Dhondup Gyal (1953-1985). There are artist characters in the main roles in two of his short stories. The story "sGrung pa" ("The Bard") expresses the sufferings of a person devoted to his artistic vocation because of outside pressures and torture. In "Sha dang rus pa'i brtse dungs" ("The Love of Flesh and Bone"), the main character is a thangka painter, and one of his paintings - a thangka - also has a significant role in the story. Dhondup Gyal was from Amdo, the north-eastern part of Tibet, which is today a part of the Chinese province of Qinghai. He is considered a pioneering Tibetan writer, whose literary output was created largely in the first half of the 1980s, before his untimely death in 1985 when he was only 32 years old. Dhondup Gyal's literary works include prose, poetry, essays, research, translations, and commentaries. Most of his prose works are short stories or novellas. The volume of his collected works containing stories also include two unfinished writings, which appear to be intended to be longer prose works.

Dhondup Gyal's short story "Sha dang rus pa'i brtse dungs" provides the reader with a portrait of Wangden (dBang ldan), a Tibetan thangka painter and statue maker. ${ }^{7}$ The story has two important themes: the development and life of an artist and the love between parents and their children. It is structured to have a frame story and a centre story; the former is told by a first-person narrator, Luchug (Klu phyug), who is depicted as the writer of the story, while the latter is told by the artist character himself, who relates memories from his childhood and early career as an artist.

The other short story by Dhondup Gyal, "sGrung pa", ${ }^{8}$ appeared in 1981, a couple of years earlier than "Sha dang rus pa'i brtse dungs". " "sGrung pa" has also been noted in earlier Western research on Dhondup Gyal; for example, Stoddard (1994: 828) has given concise information on this story in her discussion on Dhondup Gyal's first book 'Bol rtsom zhogs pa'i skya rengs ("The Dawn of Clear Writing"). I shall here examine "sGrung pa" as an artist story. Published in Dhondup Gyal's first book, ${ }^{10}$ it is twelve pages long and divided into four parts, ${ }^{11}$ which are

\footnotetext{
7 This short story can be found in the second volume of Dhondup Gyal's collected works (Don grub rgyal 1997: 156-192). It was originally published in 1984 in the sBrang char literary magazine under Dhondup Gyal's pen-name Rangdrol (Rang grol 1984). There exists a French translation by Françoise Robin of this short story; see Thöndrupgyäl 2007. For information on some other works by Dhondup Gyal, see Shakya 2000: 35-39.

8 The spelling of the second syllable of the title of this work varies in the 'Bol rtsom zhogs pa'i skya rengs. On the first page of the story, the word is spelled with $b a$ as sgrung ba, but in the table of contents it is spelled with $p a$ as sgrung $p a$.

9 Erhard (2019: 223, n. 10) informs that "sGrung pa" was originally published already in 1979. It is common that Tibetan stories may first be published in newspapers or journals before their inclusion in a collection of writings. I wish to thank Franz Xaver Erhard for kindly sharing with me his article, which has subsequently been published. Lama Jabb (2015: 71-72), who has also discussed this story, informs that it was first published in The Qinghai Tibetan News.

10 This story of Dhondup Gyal is also found in the volume containing "stories" (brtsams sgrung); see Don grub rgyal 1997, II: 318-328). The location of this story in this particular one of the total of six volumes suggested first to me its classification as a short story, which is usually characterized by fictionality. However, in her article about Dhondup Gyal, Heather Stoddard writes that it had an autobiographical inspiration and tells about a Gesar bard whom Dhondup Gyal knew when he was a child (Stoddard 1994: 828). Thus, the story was likely based on real-life experience. However, it has been modelled in the shape of a short story; it does not, for example, state exact place names, exact personal information of years of birth and death, or exact years of events. That said, the story can be placed chronologically based on a hint in the text itself.

11 Don grub rgyal 1981: 36-48. The parts are marked with Tibetan numbers from 1 to 4 spelled out in letters enclosed in brackets.
} 
told by a first-person narrator. Its main character is a bard specialized in the Gesar Epic, an important part of Tibetan folk culture. The stories of Gesar were first told and sung orally by bards, and only since the 1950s have they been recorded in a multitude of volumes of Gesar episodes. ${ }^{12}$

I have chosen to discuss this work here since it is a relatively early Tibetan artist story and it reflects the changing attitudes and policies towards folk culture in Amdo at different points in time. Telling Gesar stories can be regarded as folk art. The main character of the story, the bard Gephel (dGe 'phel), is depicted as devoted to this oral form of storytelling. In a way, oral storytelling is an art related to literature but its medium is different, as the stories are not (at least at the time of their telling) recorded in written form by their teller. Telling Gesar stories is also connected to the idea that the stories are already "existing" and the bard just performs them by singing; however, considering the large already recorded corpus of Gesar stories, it might be hard to say which part of them are retellings of the tradition and which stories contain innovative elements introduced by creative singers. ${ }^{13}$ Gesar stories written down as texts are, of course, a valuable part of world's epic literature. When the epic is sung and recited to an audience, ${ }^{14}$ telling Gesar stories can be regarded as a form of performing arts. There is no direct mention of precise years in Dhondup Gyal's story, but based on its contents it is possible to determine that it is located between the Chinese occupation of Tibet in the 1950s and the relaxations in cultural policies in the late 1970s or early 1980s.

Tashi Palden's (bKra shis dpal ldan) novella "rGyud skud steng gi rnam shes" ("Consciousness on Lute Strings") also tells about the life of a Tibetan folk artist. It appeared in 1999 in his collection of writings bearing the same title published by the Nationalities Press (Mi rigs dpe skrun khang) in Beijing. Tashi Palden is an award-winning Tibetan writer who was born in the gTsang region of Tibet in 1962 and lives in Lhasa and works for the Tibet Daily (Bod ljongs nyin re'i tshags par) newspaper. ${ }^{15}$ His writings include several short stories and other writings and the novel Phal pa'i khyim tshang gi skyid sdug ("The Life of an Ordinary Family"). ${ }^{16}$ According to the author's note at the end of the novella, this work was written in Lhasa in 1991, about a decade later than the two short stories by Dhondup Gyal discussed above. "rGyud skud steng gi rnam shes" is a novella with well over one hundred pages. ${ }^{17}$ In addition to this novella, Tashi Palden's collection of writings rGyud skud steng gi rnam shes also contains two other relatively shorter works and an afterword (mjug byang).

"rGyud skud steng gi rnam shes" tells about the life of a Tibetan woman named Pedron (Pad sgron), a performing artist who plays the lute and dances. This novella belongs to the genre

\footnotetext{
12 About the Gesar stories and about how they are sung by bards telling the epic, see Samuel 1996. For information on Gesar stories and the compilation of the epic, see Fitzherbert 2010, which also includes a translation of an article about the life of Dragpa (Grags pa), a famous Gesar story singer.

13 Samuels (1996: 361) explains that innovations in Gesar stories may be explained by Tibetans holding the view that they are "memories of a previous life in which the singer or author was one of Ge sar's followers".

14 Singing and reciting are the two ways in which the Gesar epic is performed by bards, according to Stein (1972: 278-279). He explains that songs comprise the main part, and then there are narrative parts which are recited.

15 Information on these awards can be found on the back flap of the front cover of rGyud skud steng gi rnam shes and also in mTsho sngon bod yig gsar 'gyur khang 2006: 36.

16 This novel has been discussed by Shakya $(2004 ; 2018)$ and Virtanen $(2000: 28 ; 2018)$. Charles Ramble's recent article (2019) also contains a synopsis of the novel.

17 bKra shis dpal ldan 1999: 1-119.
} 
of female Bildung ${ }^{18}$ and depicts the development of a woman folk artist from her childhood to old age. Thus, the novella spans decades, comprising a long period of Tibetan history, first depicting the life and conditions of a wandering musician and performer in Tibet during the first half of the twentieth century, then the time after Tibetan society fell under Chinese Communist rule in the $1950 \mathrm{~s}$, and finally a more recent era, when she becomes recognized as a folk artist.

The fourth story examined is Tsering Dhondup's novel sMug pa ("Fog"). A TibetanMongolian writer from Amdo, ${ }^{19}$ Tsering Dhondup (Tshe ring don grub, b. 1961) is the author of several short stories and at least three novels. ${ }^{20}$ His novels are titled Mes po ("Forefather"), sMug pa, and Rlung mar 'ur 'ur ("The Red Wind Scream"). ${ }^{21}$ The second of his novels (sgrung ring), ${ }^{22}$ being over two hundred pages long, sMug $\mathrm{pa}$ was published in 2002 by Zhang kang gyi ling dpe skrun khang (and printed in Xining). ${ }^{23}$ The language of the novel is basically Tibetan, but the text also includes some Chinese and English. The reader does not have to be fluent in these two other languages, since a Tibetan translation is given in brackets after specific words or passages. According to the author's dating at the end of the novel, its writing was completed in the beginning of 1999. This novel has also been discussed by Franz Xaver Erhard (2019) from the viewpoint of power and hegemony. In 2014, the Tibetan scholar Tsunpo Dhondup (bTsun po don 'grub) offered a new contribution in Tibetan to the existing research on Tsering Dhondup's writings. In his study Tshe ring don grub kyi sgrung gtam la dpyad pa ("Examining Tsering Dhondup's Stories"), he has also discussed the novel sMug pa and the interpretation of its central image (bTsun po don 'grub 2014: 222-224).

Mainly located in Amdo in a place called rTse gzhung rtswa thang, the grassland of Tsezhung, in addition to being an artist story $s M u g ~ p a$ is also a love story. Its main character is a Tibetan

18 Although works of female Bildung are often stories by female authors, development stories of women characters can be and are written by male authors as well.

19 Tsering Dhondup (Tshe ring don grub 2006: 19) has himself provided information about his life and development as a writer in his essay "Nga rang shes med tshor med ngang nas gsar rtsom las la zhugs" ("I started writing before I realized"). Yangdon Dhondup (2002) has written about issues connected to identity and the marginalization of Mongolians who have adopted Tibetan language and culture in Qinghai, and has also discussed two Mongolian-Tibetan writers, Tsering Dhondup and Jangbu (JJang bu), and their literary work. Furthermore, information about the life and works of Tsering Dhondup can be found in Chabdrag Gonpo Kyab's (Chab brag mGon po skyabs) preface to a volume edited by him, which contains a collection of essays in which Tsering Dhondup's literary works are discussed in the preface titled "'Go brjod mthong thos dran gsum ma"; see Chab brag mGon po skyabs 2011: 1-14. In the present article, Tsering Dhondup's name has been spelled in English in a style that gives an idea of its pronunciation and in a similar style as other Tibetan names in the text (using Wylie transliterations in brackets). On the cover of $s M u g ~ p a$, however, in addition to his name in Tibetan letters, his name is spelled with English letters as Tsering Dondrup.

20 Tsering Dhondup's novels have their titles printed on their cover also in English. After the original writing of this article, according to information provided by Erhard (2019: 225), Tsering Dhondup published one more novel titled Nga yi a pha gnyis ("My Two Fathers") in 2015.

21 According to information presented by Chabdrag Gonpo Kyab, Tsering Dhondup has also published stories and essays in Chinese and edited in both Tibetan and Chinese several books on various topics (Chab brag mGon po skyabs 2011: 5).

22 As modern Tibetan literature is still a comparably new literary development, there has not yet appeared a sufficiently large number of novels that would make it feasible to focus only on novels when examining artist stories (or at least such works have not been available to me at the time of writing). A large bulk of Tibetan modern literature has appeared in literary magazines, and this format favours shorter works, although some novels have also first appeared in parts in series in literary journals. The number of Tibetan novels is growing all the time, but there are still not many novels appearing annually in Tibetan language.

23 I would like to thank Franz Xaver Erhard for helping me to obtain a copy of $s M u g$ pa as well as several other fascinating publications. According to Erhard (2019: 225), a second edition of $s M u g$ pa has been published by Sichuan Nationalities Publishing House. 
writer named Sengge (Seng ge), and the novel depicts his relations with other characters, most notably two women: his American new girlfriend Judy, who is a scholar of Tibetan literature, and his Tibetan old girlfriend Metog (Me tog), who prefers to speak Chinese and is a painter of modern art. It focuses on a time in his life when the American girl becomes part of it and when he starts planning to go to America to live there with her. Recently, two essays in Tibetan about sMug pa have appeared in a collection of scholarly writings on Tsering Dhondup's works; to these can now also be added an article by Erhard (2019). The authors of the Tibetan articles insightfully view the three characters - Sengge, Metog, and Judy - as representing three different cultural tendencies now present or having the potential to influence culture in Tibetan society in the People's Republic of China. Sechang Sangdon observes how the three characters are moulded by their respective cultural environments (bSe chang Sangs don 2011: 181), whereas Jampa Tsultrim has examined the relations between the three characters and points out how these form central tensions in the novel. Jampa Tsultrim shows how these relations are not merely relations between Sengge and his former and present girlfriends, but how these characters and their ways of thinking are influenced by their cultural upbringing and preferences, highlighting the importance of the cultural discourse presented in the novel. He also interprets Sengge's disagreements with Metog and his attachment towards Judy in the context of the character's attitudes towards cultural choices and the values they represent (Byams pa tshul khrims 2011: 196-204).

Tsering Dhondup himself has described in an essay the way he received inspiration for his works. He tells how his father worked as a smith and how people of nearly all walks of life came to their house. In his list of people from various professions who visited and inspired his writing and the creation of his characters with their stories, he does not mention writers but a Gesar bard, for example. In descriptions of his school years and later career, however, it becomes evident that while still quite young he became acquainted with some well-known writers, too (Tshe ring don grub 2006: 20-21).

\section{THE ARTIST CHARACTERS}

\subsection{Development as an artist}

All the works discussed here have artist characters as their main protagonist. In two of the works, it is described how the artist learns his or her profession from a parent. These works are Dhondup Gyal's "Sha dang rus pa'i brtse dungs" and Tashi Palden's "rGyud skud steng gi rnam shes". The main character Wangden (dBang ldan) in Dhondup Gyal's "Sha dang rus pa'i brtse dungs" is a thangka painter and statue maker, and in the story he is called "A khu lha bzo" ("Uncle deity maker") by the narrator and others. ${ }^{24}$ It is understood from the content that thangka-painting and statue-making comprise the profession of the family and community. Indeed, the story is set in Amdo, where there are areas that are famous for their thangkas. In the central story narrated by Wangden himself, he tells how in his childhood he was taught how to paint by his father, who was a thangka painter and statue maker. The story contains a description of how Wangden takes as a model a thangka painted by his father and paints a similar-looking goddess. In the following excerpt, Wangden's father helps him to perfect the expression of the goddess in his sketch:

24 Don grub rgyal 1997: 160-161, 173. 
phyi nyin/ khong gis ngas bris pa'i ri mo de rnams la zhu dag mdzad pa dang/ khong gis gzab nan gyi sgo nas lha mo'i gdong ris de la pir shad 'ga' las ma 'then yang/ pir shad de dag gis ngas bris pa'i ri mo de'i rnam pa yongs su bsgyur ba dang/ khong gis phyag bris mdzad pa'i thang ga de dang khyad par med par btang song/ngas khong gi pir kha len stangs la zhib tu bltas rjes/ rang gi dang thog blo de lta bu ma dran pa la 'gyod pa skyes par ma zad/ a pha'i pir rtsal ni ngo ma khyad du 'phags pa zhig red ang snyam byung/ de'i rjes su ngas a pha'i bkod pa ltar lha mo de'i gzugs brnyan thang ga chen po zhig gi thog tu bris pa dang/ a phas yid tshims pa'i ngang nas mgo lcog ldem ldem byed bzhin par/nged tshang gi ban ngos la bkal song/(Don grub rgyal 1997: 172)

The next day he checked my sketches. He did not do anything more but carefully drew a few brush lines on the face of the goddess. However, those few brush lines completely changed the expression of my drawing and made it look similar to the painting he had painted. I closely followed his technique of using the brush and felt remorse that I had myself not understood it from the beginning. I thought that Father's skill of using the brush was really very special. After that, in accordance with the model of Father's [painting], I painted the shape of that goddess on a big thangka canvas, and Father, nodding his head approvingly, placed [the painting] on the face of a cupboard in our house.

As we saw in the above excerpt, the student, who is in this case the son of his teacher, creates a work of art by careful imitation; the aim is to skilfully produce a counterpart of an already existing model. Such an approach works towards preserving the tradition and suggests also a craft-like approach towards painting: learning from a model appears to be stressed over imaginative creativity.

In "Sha dang rus pa'i brtse dungs", Wangden relates how his father invited the other painters of the community to be present at a ritual to consecrate the painting after it had been successfully completed and to celebrate how his son had completed his studies. ${ }^{25}$ Thus, Wangden was accepted as a professional artist. However, some special moments of the inner "consecration" or "transformation" of becoming an artist are not described in the scene. In his Ivory Towers and Sacred Founts (1964), Maurice Beebe writes about Western books with a "portrait of the artist". For example, he cites Rousseau's "moment of transformation", quoting a letter in which Rousseau describes a kind of sudden illuminative state of mind in relation to the powerful experience of becoming an author (Beebe 1964: 40-41). ${ }^{26}$ This kind of inner "consecration" is often regarded as a moment of becoming a "real artist" in the Western tradition.

We shall take a brief look at such a moment in one well-known Western artist novel and then contrast it with Tibetan descriptions of becoming an artist. In Joyce's novel A Portrait of the Artist as a Young Man, its main character Stephen Dedalus is also depicted as experiencing a special moment - a vision of "a winged form flying above the waves and slowly climbing the air" while walking outside (Joyce 2016: 156). The narrator describes the ecstatic state he enters and how he then realizes a strong calling to be an artist, which is described in the novel as follows:

His soul had arisen from the grave of boyhood, spurning her gravecloths. Yes! Yes! Yes! He would create proudly out of the freedom and power of his soul, as the great artificer whose name he bore, a living thing, new and soaring and beautiful, impalpable, imperishable. (Joyce 2016: 157)

Before this ecstatic and visionary scene, Stephen had been reflecting on the possibility of becoming a priest, since the director of his school had suggested that vocation, but he had decided not to choose such a path (Joyce 2016: 142-153). Beebe (1964: 282-283) has described

25 See Don grub rgyal 1997: 172.

26 The source of the excerpt in Rousseau's letter is identified by Beebe (1964: 40, n. 51) as Charles William

Hendel's Citizen of Geneva: Selections from the Letters of Jean-Jacques Rousseau (NY: OUP, 1937). 
this special moment of becoming an artist as "Stephen's moment of transcendent dedication", calling this scene "the consecration scene of the Portrait".

When discussing the features of Tibetan artist stories, it is also worthwhile to try to understand if there could be an absence of some features typical to Western works of the genre or if some features are given less emphasis in Tibetan stories. In Dhondup Gyal's story, such a moment of inner transformation or calling to becoming an artist is not depicted. On the contrary, it is the object of art, the painting, which is consecrated ritually. In "Sha dang rus pa'i brtse dungs", becoming an artist is transmitted in the family and learned as a result of studying painting and statue-making under the guidance of the father. The father invites other painters to view the painting accomplished by his son, and Wangden describes his emotional state during the occasion, telling how happy and proud he felt when praised. ${ }^{27}$ This scene conveys the joy of accomplishing the painting successfully, as well as the idea of how the profession of a thangka-painter is passed on from one generation to the next. If we compare the type of sudden experience of inner transformation experienced by Rousseau or the ecstatic and visionary realization of Stephen's calling to be an artist in Joyce's novel with the way of becoming an artist depicted in Dhondup Gyal's short story - learning from one's parent - they appear to be very different, with the former including sudden, inner experiences and the latter involving a long process of learning under the guidance of a teacher. The way in which the process of becoming an artist is depicted in different literary traditions can provide indications about cultural conceptions related to the artistic profession. The process of learning a profession from a parent can be regarded as a very practically oriented approach to art (such as learning a skill to support oneself economically), whereas the approach typical of Western artist stories, of suddenly realizing one's calling as an artist, can be thought as a sudden realization or even resembling a mystical revelation.

In Tashi Palden's "rGyud skud steng gi rnam shes", the performing artist Pedron (Pad sgron) also learns her profession from her father. The novella contains a description of her first performance trip outside her village with her father when she is about ten years of age. ${ }^{28}$ In a scene where she performs with her father for an audience in a fortress, her father plays the lute and Pedron sings with him and dances at the same time. The narrator describes how hearing her father play the music helped her to overcome her nervousness when she had to perform in front of the lord. ${ }^{29}$ This is how the narrator describes their performance:

pad sgron gyi skad gdangs phra la snyan pa'i gzhas dang lham gyi rtse nas mthe bong phyir thon pa'i rkang chung gis zhabs bro rgyag tshul de ni ltad mo che yang ya nga ba zhig yod cing/skabs 'gar pad sgron gcig pus zhabs bro rgyag pa dang skabs 'gar pa phas sgra snyan mjing pa dang rgyab tu 'khur nas dkrol bzhin mnyam du zhabs bro brgyab pa bcas kyis a jo' $i$ 'khrab ston la gson shugs gsar pa sprad pas ltad mor dga' ba'i sku ngo dpon g.yog rnams kyang yid dbang 'phrog pa dang sems 'gul thebs thag chod nas gnang sbyin gang legs sprad pa ma zad pad sgron la dmigs te gyon chas rnying pa kha shas byin/ (bKra shis dpal ldan 1999: 23)

The way how Pedron sang in her high pitch and pleasant voice and how her small feet took dance steps, the big toes showing from the tips of her shoes, was a great spectacle and also somewhat sad. Sometimes Pedron was dancing alone and sometimes father carrying the lute on her neck and back played it and danced together with her. [This] gave a new energy to the show of Ajo [and] also the nobles and their servants were attracted by [it], and since they had gotten deeply moved they generously donated gifts and, moreover, gave some old clothes, especially for Pedron.

27 Don grub rgyal 1997: 172.

28 bKra shis dpal ldan 1999: 19-23.

29 bKra shis dpal ldan 1999: 22-23. 
In the above excerpt, the name "Ajo" refers to Pedron's father. It is explained that this was not his real name, but an artist name that he had received, based on a particular song he sang. ${ }^{30}$

During their performance trips, the father and daughter wander around and perform outside to audiences of ordinary people, as well as in the fortress for an upper-class audience. The Tibetan society during Pedron's childhood is depicted as still having strict class divisions between aristocrats and ordinary villagers, indicating a time before the 1950s and Tibet coming under the rule of the PRC. The narrator tells how after this first performance trip, Pedron continues to accompany her father on others until she becomes an adult and is employed in the fortress as a performer. ${ }^{31}$ There is also a description of the development of her artistic skills; it is told how during their trips she starts to play the lute and is even able to both play and dance at the same time in a similar way as her father. Her special skill is to perform while at the same time balancing a cup of beer (chang) on top of her head. ${ }^{32}$

It appears for the reader that, living in a family where one of the parents was a musician and performer, Pedron must have heard music and seen dancing since early childhood. Accompanying her father during her youth on trips where they performed together, playing the lute and dancing appear so natural a part of her development that in this novella also there is not some special moment of transforming into an artist, although the moment when she manages to concentrate on the music, overcoming her nervousness during her first performance trip, appears to be a decisive moment in her career. However, the lack of an initial sudden realization of one's inner nature as an artist does not mean that the character in this novella is lacking a sense of "calling" to be an artist. It could be interpreted rather that the sense of calling is so deep and natural that it is an integral part of her life.

In Dhondup Gyal's "sGrung pa", we do not hear anything about how the main character Gephel (dGe 'phel) became a Gesar bard, except for his words to the narrator, which reveal that he has been singing since his childhood and the time he learned to speak even. ${ }^{33}$ The work does not describe the becoming and growth of a folk artist, but only some moments of his life, such as when the narrator meets him or receives information about him. Yet, in Fitzherbert's article about Gesar epics, there does exist information on how one real person named Dragpa (Grags pa) became a Gesar bard; this is based on his translation of "The Biography of Grags pa", a Tibetan text by Coepa Dhondup (gCod pa don grub) and Chabgag Dorje Tshering (Chab 'gag rdo rje tshe ring). ${ }^{34}$ According to the biography, Dragpa was a famous Gesar bard who possessed and was able to perform a vast repertoire of Gesar stories (Fitzherbert 2010: 226-228). It is also revealed that an event of a mystical nature was connected to his becoming a Gesar bard: namely, he disappeared for some time when he was still a child, slept for an unusually long time, and saw a dream in which his stomach was filled with stories of King Gesar (Fitzherbert 2010: 228-229). In this real-life account, being a Gesar bard is not an inherited family profession, but rather something that is suddenly given. Here there

\footnotetext{
30 bKra shis dpal ldan 1999: 21.

31 bKra shis dpal ldan 1999: 21-27.

32 bKra shis dpal ldan 1999: 25: da ni pad sgron gyis kyang sgra snyan gtong shes pa ma zad pa pha ltar sgra snyan mjing pa dang yang na rgyab tu 'khyer nas zhabs bro 'khrug thag chod rgyag thub kyi yod pas mi tshad da dung phor pa'i nang chang phyed tsam blugs te mgo bo'i steng du bzhag pa dang sgra snyan rgyab tu khyer nas dkrol gtong ba dang zhabs bro rgyag thub kyi yod pas mi tsho'i yid dbang 'phrog.

33 Don grub rgyal 1981: 41.

34 The bibliographic details of the original Tibetan text are given by Fitzherbert (2010: 226) as gCod pa don grub and Chab 'gag rdo rje tshe ring, Ya mtshan che ba'i gling ge sar sgrung pa'i gsang ba (Beijing: Nationalities Publishing House, 2001): 52-63.
} 
could be something similar to Rousseau's experience of a sudden transformation (Beebe 1964: 40), except transformation during a dream sounds even more mystical.

In Tsering Dhondup's $s M u g p a$, the main character Sengge has acquired a modern education in school. In this story, therefore, becoming a writer is not something transferred within the family, but rather a unique career choice based on literacy skills required at school. This work could be viewed as a portrait of a new type of Tibetan intellectual, characteristic of the last couple decades of the twentieth century and the present millennium. The novel does not systematically depict Sengge's development and path as a writer. However, it contains flashbacks about Sengge's earlier life, when the reader hears about his time in school and work to improve Tibetan school education. ${ }^{35}$

Sengge's home is in the nomadic area of the grasslands of Amdo, where families keep animals such as sheep and yaks. ${ }^{36} \mathrm{He}$ has a chance to go to school and is described as hard-working and intelligent, and becoming an excellent student he continues his studies at the university. ${ }^{37}$ In earlier times, generally speaking, there were many children in the nomadic area who did not receive education; the chance to become literate was often tied to attaining some religious training. However, in modern times at least some of the ordinary people from nomad areas have gained the opportunity to go to school. A school education and acquiring the skills of reading and writing can thus be understood as a necessary basis for Sengge's later career as a writer. Not described in the text are the way in which Sengge took an interest in writing, some special moment of "calling or realization to become a writer", or his development as a writer. Instead, it only tells how he "gradually arrived at the highest peak of Tibetan literature" ${ }^{38}$ However, it can be understood from a scene near the end of the book that Sengge had a great liking for reading. Here he is depicted making preparations to leave to America with Judy, and he wonders what he should do with his many books. His relation to his books is described as follows:

nyin 'di gar khos sems khral byed bzhin pa'i don dag cig ni 'di 'dra'i dpe cha mang po 'khyer thabs med la bskyur 'dod kyang med pa de yin/ dpe cha 'di dag ni kho pa'i lo ngo bcu lhag ring gi slob dpon yin la grogs po'ang yin/dpe cha 'di dag gi ched du khos gyon pa bzang po zhig nyo ma phod la ljongs rgyu mang po'ang byed ma phod/ mdor na dpe cha 'di dag ni rang gi rgyu nor nyag gcig po yin la rang gi tshe srog dang gnyis su ma chis pa'i brtse 'dang yang yod/(Tshe ring don grub 2002: 198)

These days he was worried about one thing: it was not possible to carry [with him] so many books, but [he] also did not wish to throw them away. These books had been for over ten years both his teacher and his friends. For the sake of these books he had not dared to buy good clothing or travel much. In brief, these books were his only property and he loved them as much as his life.

\footnotetext{
35 In addition to descriptions of artist life, the novel also contains some other socially critical content, telling in a subplot the sad story of a Tibetan girl who falls ill and dies after going to work in town. She had been given work in a bar where the work of entertainers resembles that of prostitutes (Tshe ring don grub 2006: 128-137). 36 Tshe ring don grub 2002: 145-151. It is not said in the novel explicitly whether Sengge and his parents are Tibetans (or perhaps Tibeto-Mongolian). However, since his language and culture are described as Tibetan and his writings are viewed as Tibetan literature by other characters (see Tshe ring don grub 2002: 12), the main character could be considered Tibetan. From the novel it can be understood that in its milieu, the grassland of rTse gzhung, there is also one group in the settlement which is Mongolian in its origin but is now said to have "largely become Tibetan" (da lta phal cher bod du gyur zin pa'i sog po 'i ru sde; Tshe ring don grub 2002: 24). The location of this part of the settlement appears to be different from the location of Sengge's house, since his Japanese friend Yokho (Yo kho), who is interested in the history of the Mongols, is planning to visit there (see Tshe ring don grub 2002: 27). Regardless of the exact ethnic origin of the fictional protagonist, in the novel he is presented as a writer who has created a significant literary output in Tibetan language, making a contribution to Tibetan literature.

37 Tshe ring don grub 2002: 118 .

38 Tshe ring don grub 2002: 30, 116-118.
} 
From the quoted excerpt it can be understood that Sengge considers that he has learned much from his books, since he holds them as his "teacher" (slob dpon) and he values them highly. After some thinking, he makes a decision which later proves fateful to his trip: to donate them to a library.

In two of the works, Dhondup Gyal's "Sha dang rus pa'i brtse dungs" and bKra shis dpal ldan's "rGyud skud steng gi rnam shes", the artists - a thangka painter and a musical performer - learned their profession from their fathers. Thus, the profession is depicted as passed on within the family (even though in these stories there were no depictions of earlier generations), and becoming an artist appeared as a natural developmental process that progressed from youth to their maturity as adults. Learning from a master as an apprentice is one of the features connected to Bildung stories (see Abel, Hirsch \& Langland 1983: 11), but in this Tibetan context there is notably also the relation of a parent and a child at the same time as that of master and disciple. In one of the works, the reader does not learn anything more about the initial stage of becoming an artist, except that the main character, a Gesar bard, had started singing in early childhood. Nor does Tshering Dhondup's $s M u g$ pa present any decisive moment of becoming an artist, but it can be understood that Sengge has acquired a school education, which provides the basic skills for writing, and he has also read a lot of books. In the main timeframe of the narration, Sengge is already depicted as a mature writer. In these works no mystical moments of sudden transformation into an artist nor sudden "callings" to become one are depicted, thus suggesting that the Tibetan views of a person becoming an artist often tend to be more practical.

\subsection{The artists: lifestyles and artistic activities}

Next we shall take a look at the artist characters and how their artistic activities have been described in the stories. The title of Dhondup Gyal's short story "sGrung pa" can literally be translated as "Storyteller". The identity of the main character as a Gesar bard is revealed from the childhood reminiscences of the first-person narrator, who functions as the focalizer of the story. ${ }^{39} \mathrm{He}$ tells how in his childhood, he and other villagers had come to listen to the bard outside under a special tree near the bard's house. The tree is special since, according to the way the bard always starts his stories, its seed was sown by King Gesar himself, who had fetched it all the way from Mount Kailash. ${ }^{40}$ This special tree, mentioned several times in the story, also seems to be used to reflect the attitudes and situation of folk culture in different times. ${ }^{41}$

The story contains little information about the outer appearance of the bard. When in Part 1 the narrator sees the bard under the tree, we only hear that he first notices there a man whose bodily size is quite big. ${ }^{42}$ Evidently the bard is also quite aged by the time the narrator meets him during his visit to the village (in Part 2); this is revealed by the way in which he refers to himself with the words "I, old man" (nga rgad po; see Don grub rgyal 1981: 41). The audience is also told by the narrator that the bard is a single man with no wife or children. ${ }^{43}$ The reader gets some idea about the bard and his thoughts by means of his speech, which is marked with some features typical of the Amdo dialect, and the character becomes more alive through his

\footnotetext{
39 On the concept of focalization in narratives, which was introduced by Gérard Genette, see Rimmon-Kenan 1983: 71-85. In Dhondup Gyal's "sGrung pa", the storyworld and its main character, the bard (the focalized), are perceived from the point of view of the first-person character-narrator (the focalizer).

40 Don grub rgyal 1981: 37-38.

41 Don grub rgyal 1981: 36-38, 43-44, 46.

42 Don grub rgyal 1981: 37.

43 Don grub rgyal 1981: 39.
} 
voice. The story has a passage which describes the bard singing Gesar stories in his house in the evening. Here the voice of the bard and its influence are described in a poetic way:

\begin{abstract}
skad snyan zhing ngag bde ba'i sgrung skad de khang ba'i sge'u khung nas 'phur te a sngon dbyings su khyab pa dang/ nya gang zla ba'i zhal ras ni 'dzum pa'i tshems phreng dgod bzhin sngo bsangs lha lam yangs po'i ngos na dal bur bskyod cing/smin drug khra mo'ang yid smon skyes te dbu ske g.yon pa'i tshul gyis zur mig lta bzhin 'dug (Don grub rgyal 1981: 43)

The pleasant and fluent words of the epic flew out of the window of the house and sounded in the sky, and the face of the full moon was smiling and moved slowly in the wide blue sky and the shining Pleiades ${ }^{44}$ felt admiration and, turning their heads towards the left, were looking from the corners of their eyes.
\end{abstract}

The bard's devotion to his art of storytelling becomes clearer with the context of the above excerpt: the bard is singing in the evening in his house, even though the preceding conversation between the narrator and the bard reveals that he knows about the restrictions on singing and telling stories. According to research literature, these kinds of restrictions on expressions of Tibetan culture existed during the Cultural Revolution in 1966-1976. ${ }^{45}$ The bard does not take these seriously; telling stories is such an integral part of his life that instead of doing it under the tree outside he now sings in the evening inside his house, where the local people gather to listen to him.

In Dhondup Gyal's "Sha dang rus pa'i brtse dungs", the first-person narrator of the frame story tells how he met the artist Wangden for the first time on the road when returning to school. The appearance of the artist, at that time in his forties, was such that it initially caused the narrator to be frightened. The artist is described as lame (mi 'theng bo, rkang ba 'theng bo) and his back bent, but his eyes are bright. The narrator comments that, leaning on his stick, he resembles "a vulture who has landed on a boulder". ${ }^{46}$

Apart from the description of how Wangden learned painting from his father and the focus on the thangka of the goddess he painted then, there is little in this short story about his activities as an artist after the completion of his studies. When the artist tells about his life to the narrator, most of his story concerns a trip he made with his friends when they were young. Wangden describes how when he secretly left home he took with him the equipment of an artist (lha bzo'i yo byad). During this trip in different places around Kokonor Lake in Amdo, he and his friends supported themselves and gained wealth by creating sacred paintings, described simply as "various thangkas of peaceful and wrathful [deities]" (zhi khro'i thang ka sna tshogs) ${ }^{47}$ Unfortunately, however, when they became victims of robbers, Wangden's back was injured and he lost all the wealth he had gathered. When he was receiving treatment from a famous doctor of Tibetan medicine in Bla brang, the doctor asked him to construct a statue of Medicine Buddha. Characterized as "a clay

\footnotetext{
44 The translation of sMin drug follows Chandra Das's dictionary, which defines it as follows: "the Pleiades, or the third lunar mansion, having fire as its regent; this constellation, containing six stars, is represented as a flame or else as a razor or knife. The stars represented as nymphs are said to have acted as nurses to the god Kartikeya" (Das 1991: 991). Especially interesting in regards to the passage in Dhondup Gyal's story quoted above is the information that the stars have been "represented as nymphs", which anthropomorphizes them.

45 See Smith 1997: 545. Morcom 2010: 396, n. 25 also mentions the suppression of Tibetan traditional songs during the Cultural Revolution; her information is based on a work by an anonymous author, Unity and Discord: Music and Politics in Contemporary Tibet (London: Tibet Information Network, 2004).

46 Don grub rgyal 1997: 159-162.

47 Don grub rgyal 1997: 179.
} 
statue of the Medicine Buddha of the size of eight 'dom ${ }^{48}$ measures" (sangs rgyas sman bla' $i$ 'jim sku 'doms brgyad ma), it took over a month to complete. Wangden meets again in Bla brang one of his travel companions he had lost during the attack of the robbers, and they complete the statue together, giving it the final touches. ${ }^{49}$ From the artist's narration the audience can piece together some financial information related to the work of statue construction: Wangden does not have to pay for his medical treatment and he receives full room and board in the monastery during the period of work. At the end, he and his friend receive as payment and award "silver worth two times 50, and two bricks of tea" (dngul lnga bcu ma gnyis re dang/ja bag cha re), as well as khata greeting scarves. ${ }^{50}$ Not given in these passages related to his artistic activities during his travel in his youth are the thoughts of the artist on his art, but rather how he earns with his artistic skills. Wangden tells that he rested in the forest the night after the robbery, missing his father and thinking about his kindness, reflecting on how he had learned the skills of painting and sculpting from him and how he could thereby support himself to live independently. ${ }^{51}$ In this short story, painting is described as a practical profession and a means to earn a living, rather than some kind of special "calling". More emphasis is given to the relation of Wangden and his father, and the pain he feels upon realizing that his father had passed away while he was travelling. As an expression of his pain he cuts his own leg with a knife; this injury explains how he became lame. ${ }^{52}$

In Tashi Palden's "rGyud skud steng gi rnam shes", Pedron is described as devoted to playing her lute. A passage in the beginning of the novella exposes the meaning of the title of the work ("Consciousness on Lute Strings"). Pedron is climbing a mountain pass with her granddaughter and at the same time playing her Tibetan lute (sgra snyan). ${ }^{53}$ The narrator describes her relation with the lute, which also reveals the depth of her inner feelings of being a musician:

sgra snyan ni mo'i 'gro ba'i 'gro rogs dang/ nyal ba'i nyal rogs/ sems pa skyo skabs kyi sems gso gtong byed dang/ spro snang skyes skabs kyi dga'ston byed rogs rang yin pas mos sgra snyan der ha cang gces spras byed pa de yang sgra snyan gyi rgyud skud drug po de mo rang la mtshon na ha cang rgyus mnga' can gyi grogs po zhig dang 'dra bas mo la dga'sdug gi bya ba gang zhig byung yang rgyud skud drug po de'i mtha' 'khor las brgal med pas mo'i dga'skyo khro sdug gi 'tsho ba' $i$ rol gdangs cha tshang rgyud skud drug po de'i steng du bris yod ces bshad chog (bKra shis dpal ldan 1999: 1)

\footnotetext{
48 Don grub rgyal 1997: 187. The word 'dom (without sa yang 'jug) is explained in Goldstein's dictionary as follows: "a length measure defined as the span of a person's outstretched hands from fingertip to fingertip" (Goldstein 1975: 609).

49 In Tibetan, gser phul and zhal bsros (Don grub rgyal 1997: 189). This means painting the statue with gold and painting the facial features and other details.

50 Don grub rgyal 1997: 187-189.

51 Don grub rgyal 1997: 184.

52 Don grub rgyal 1997: 191.

53 The lute is a traditional instrument in Tibetan folk music. On lute music in Tibet, see Savolainen 2007. Her article is centred on music played with lute and mandolin in Amdo. According to her, their use there is a more recent phenomenon, but the lute has been popular in Central Tibet since ancient times (Savolainen 2007: 2). See also Morcom 2010: 404-407, who discusses the sgra snyan in the rdung len music of Amdo and the instruments involved in its playing. Collinge's (1993) article contains detailed information on the structural features of the sgra snyan as a musical instrument, as well as illustrations. He characterizes the sgra snyan as "a 6-stringed, long-necked, fretless, plucked lute"; Collinge (1993: 28-30) also provides a history of lute music in Tibet and its possible connections to Central Asia. In Jabb's article (2019), one can read about the life of a well-known rdung len player and singer Dubhe and about his songs. Henrion-Dourcy's introduction to a thematic issue of Revue d'Etudes Tibétaines contains a detailed bibliography of studies on Tibetan performing arts, and in its section on "traditional/folk songs and dances" it is possible to find several articles on Tibetan folk music and instruments; it also references two documentary films on the subject (Henrion-Dourcy 2017: 41-46).
} 
The lute is the friend of walking while walking, a friend of sleeping while sleeping, a consoler when she feels sad, a friend of celebrating when there is [a cause for] happiness. She cherishes her lute very much and it is as if for her the six strings of the lute are like a very close friend. Whatever joy or sorrow happens to her, since it does not go beyond the border of the six strings, it could be said that she is composing the melody of her happiness, sorrow, anger and suffering, all on top of those six strings.

Pedron sings and plays regardless of whether there are listeners or not; this has become her lifestyle and way of existence. Pedron's character is described in relation to her music and the activities related to it. When it is said that she expresses her joys and sorrows with her music, this idea is connected to the idea of art springing from experiences of life, which resembles conceptions of art classified by Maurice Beebe (1964: 13, 65-113) as the Sacred Fount tradition. For example, Beebe discusses a novel in which the main artist character appears to resemble Pedron to some extent: George Sand's Consuelo, named after its main character, holds for Beebe (1964: 77) a significant position in what he calls "the Bohemian tradition in artist fiction" ${ }^{54}$ Like Pedron, Consuelo is a singer; her lifestyle with her mother is described as a "wandering, gypsy-like way of existence" (Beebe 1964: 76-77). Having researched female artist stories from the nineteenth century, Kari Lokke (2003: 516) adds that Consuelo is "a daughter of an itinerant street musician". Thus, this European novel also presents at least two generations of musicians.

Beebe discusses several literary works with artist characters, and his description of the romantic artist type is but one type of artist of the Sacred Fount tradition. It also has essential differences from a Tibetan wandering musician. Attaching some idea of superiority or ideas of "divine calling" 55 to being an artist or to their work does not seem to fit entirely well with Tashi Palden's descriptions of a Tibetan female lute player, at least viewed in the context of her social environment. ${ }^{56}$ However, even though her art is not connected to divine qualities in its reception and valuation in her own environs, in some places of the work there are indications that her character has had a kind of inner "calling" to be a wandering musician, despite having learned the lifestyle from her father in childhood. Her story has moments when she actively chooses to be and to work as an artist; she returns to her wandering life when she has other options.

Since Tashi Palden's novella has not been translated into English, I will supply the reader with a bit more information on its contents, so that it will be easier to understand the artistic life of its main character. In Pedron's life, there was a time when she had to live without playing. She could not keep her lute, but had to leave it with a group called the "district part-time publicity unit" (rdzong las zhor dril sgrags ru khag) ${ }^{57}$ Unable to continue as a wandering musician, she had to stay in her village to do agricultural work and participate in meetings. Such descriptions suggest that this part of the story is taking place during the Cultural Revolution. Later on, when Pedron notices other musicians performing outside and, encouraged by this sight, she goes to

\footnotetext{
54 George Sand's monumental novel Consuelo was translated by Katri Ingman into Finnish; this translation was published in 1949.

55 See Beebe 1964: 85-86.

56 However, in the documentary Acho Namgyal: Shey kyi jinpa (Sonam Tashi \& Henningsen 2010), Ajo Namgyal, a famous blind lute player in Tibet, is shown requesting someone to take his lute to a temple for a blessing before a performance. In the film, Ajo Namgyal is depicted as a much appreciated artist; originally he came from a poor family, but he was found by a nobleman and received a musical training in Lhasa. The film has English subtitles.

57 bKra shis dpal ldan 1999: 48.
} 
search for her lute in order to start performing again, ${ }^{58}$ the apparent relaxation in cultural life indicates the post-Maoist period after the Cultural Revolution.

Pedron's feeling at finding her lute again is described as that of meeting a long-lost relative. ${ }^{59}$ The lute is broken and needs repairs, but she does not want any other instrument. She explains, "on this lute there is the picture of my joys and sorrows and also it has the fingerprints of several generations of my family". ${ }^{60}$ She starts to perform first in her own village and then decides to take trips outside as well. Her attitude and choice to continue her former lifestyle as a musician reflect at this time an active decision from her side, and not only because of her family background. She likes doing something which she knows how to do well. She did not enjoy staying in a house and caring for a field, and the story tells how she was not even very successful at it; she did not even earn enough to support herself, but had to borrow grain from others. ${ }^{61}$ Because she apparently was not an ideal agricultural worker, her character is not depicted as exemplary in all possible ways. The story describes that to wander around performing music represents for her the "greatest freedom" (rang dbang che shos) and "greatest happiness" (bde skyid che shos) ${ }^{62}$ Thus, her character is devoted to her art - a true artist personality. The idea of wishing for freedom from different kinds of bonds is also an important element in artist stories in the Western literary tradition. For example, the main protagonist in Joyce's Portrait of the Artist as a Young Man in the end decides to leave his country even (Joyce 2016: 234-235; Beebe 1964: 277). In addition, Kari Lokke discusses the importance of freedom for Consuelo and her artistic career, as Sand's eponymous novel also addresses the idea of artistic freedom from the bonds of romantic relationships (Lokke 2004: 119-122).

The novella includes an episode in which Pedron, already quite aged, performs on stage in Lhasa, where she has been specially invited. The narrator tells how she feels nervous for the first time in her life performing on stage in front of a big audience, but anyway feeling inspired to sing she overcomes her nervousness and "an energy comes to her whole body" ${ }^{63}$ The scene includes words from some of the songs she performs, as well as a description of the way in which she performs on stage. She not only sings but also dances. She plays while holding her lute in different positions, sometimes playing it in her lap, sometimes carrying it on her back, and sometimes hanging it around her neck. She also shows the audience her almost acrobatic skill of being able to play with a cup of chang on top of her head. ${ }^{64}$ Her performance wins a big applause and the audience calls for an encore. This scene is a description of the point when, after a long career as a musician, Pedron has become a well-known and appreciated folk artist.

The end of the novella contains depictions which convey the deep commitment of Pedron to her lifestyle as a wandering musician. When the time comes to return home, she instead decides to stay longer, even though she has to vacate her hotel room, since she wishes to visit the holy places in Lhasa. She goes to perform outside, and she plays the lute and sings in front of the Jokhang (Jo khang) temple. She is described as thinking that it is a normal part of her occupation to wander around without certainty of shelter. Performing music en plein air has become

58 bKra shis dpal ldan 1999: 50-52.

59 bKra shis dpal ldan 1999: 52.

60 bKra shis dpal ldan 1999: 53: “sgra snyan 'di'i steng du nga'i dga' skyo khro sdug gi ri mo yod la nga tsho'i

mi rabs kha shas kyi mdzub rjes kyang bsdad yod".

61 bKra shis dpal ldan 1999: 49.

62 bKra shis dpal ldan 1999: 55.

63 bKra shis dpal ldan 1999: 103-104: "lus yongs la stobs shugs rgyas pas".

64 bKra shis dpal ldan 1999: 106. 
her way of life and the thing she likes best. ${ }^{65}$ In Pedron's choice of a wandering lifestyle, we could perceive a similarity to a decision made by Consuelo, who has married a certain Count Albert. After he passes away, Beebe (1964: 76) explains, "instead of taking advantage of her new title and wealth, she leaves the castle to once again resume her career". ${ }^{66}$ In Tashi Palden's novella, the way how Pedron acts and makes impulsive choices not determined by pragmatic considerations shows her as a person who does not behave according to expectations but rather thinks for herself, making her own choices of an artistic life and career. These qualities of her character are not connected to the socialist ideals of a model worker; instead, they reflect a personality who prefers to choose her own road even after attaining success.

The Bohemian tradition of artist stories is discussed by Beebe as one type of description of artists in literature, ${ }^{67}$ and the behaviour and character of Sengge in Tsering Dhondup's sMug pa could also be characterized as having some resemblance to a Bohemian kind of artist lifestyle. ${ }^{68}$ For example, Sengge does not seem to have many inhibitions, and his actions and way of thinking are quite free of consideration of conventions. Sengge and his friends are described as drinking beer. ${ }^{69} \mathrm{He}$ is interested in women and breaks up with his Tibetan girlfriend because of his relation with an American girl, with whom he has even had sex outside in the open in nature. ${ }^{70} \mathrm{He}$ is also not bound by religious beliefs. In one scene he advises his friend to ignore a lama's opinion concerning an aspect of personal life. ${ }^{71}$ Not being dependent on others' opinions appears for Sengge to be an important characteristic of being an artist. This is apparent when he says to the friend, who does not dare to contradict the advice of a lama or ignore his stepfather, "It is impossible that you would ever become an artist." 72 Sengge's interest in the idea of freedom is underlined when - near the end of the novel, before his departure from Amdo to Beijing - he thinks about the Statue of Liberty (in New York City) and the famous words of the poem associated with it. ${ }^{73}$

Sengge has the characteristics of a Tibetan intellectual: he has a university education, and he takes interest in books and wishes to improve the education available for Tibetan children. ${ }^{74}$ As emphasized by Sechang Sangdon (bSe chang sangs don 2011: 183), Sengge has a special concern for the Tibetans. Sengge's interest in reading becomes evident in a quite detailed description of his house; he has a lot of books, both Tibetan and from other cultures, ${ }^{75}$ and there

\footnotetext{
65 bKra shis dpal ldan 1999: 108-110, 113-119. The novella also contains another folk artist character in a minor role: a woman who is a teller of Lama Mani stories (bla ma ma ni shod mkhan). She is also from a family in which the profession is passed on over generations. For the passages about this Lama Mani teller, see bKra shis dpal ldan 1999: 101, 111-112.

66 See also Lokke 2004: 117-118, 137-146, who mentions Albert's "resurrection" in the sequel of Consuelo, La Comtesse de Rudolstadt, and discusses how Consuelo opts to again become a wandering musician in the epilogue of the novel, this time wandering around with her family.

67 See Beebe 1964: 76-79, esp. 97-113, for a discussion on the theme of love and sexual relations in artist stories.

68 The Bohemian nature of this character has also been noted by Erhard 2019: 227.

69 Tshe ring don grub 2002: 4-6, 10-12.

70 Tshe ring don grub 2002: 49-73.

71 Tshe ring don grub 2002: 37-38.

72 Tshe ring don grub 2002: 38: "khyod rang nam yang sgyu rtsal pa zhig tu 'gyur mi srid".

73 Tshe ring don grub 2002: 202-203. sMug pa contains a quote from the poem "The New Colossus" by Emma Lazarus (1883).

74 Tshe ring don grub 2002: 99-105.

75 In his essay on Tsering Dhondup's sMug pa, Jampa Tsultrim (Byams pa tshul khrims) pays special attention to Sengge's familiarity with James Joyce's Ulysses and draws interesting parallels between the characters of Sengge and Leopold Bloom in Joyce's novel (Byams pa tshul khrims 2011: 193-194).
} 
is a statue of Sarasvatī, the goddess of art and learning. ${ }^{76}$ While readers do not learn much about the style or content of Sengge's literary works, except the title of his new novel manuscript, "Bre ser 'brong gi mig chu" ("The Tears of the Wild Yak with a Brown Mane"), ${ }^{77}$ a quite puzzling expression is used to describe Sengge's attachment to his house, where he "furiously completed many writings". ${ }^{78}$ The choice of this particular adverb is not explained further, but it may suggest that Sengge's writings were critical, arising from some kind of anger towards social problems, or perhaps conducted in a very energetic way, "furiously". Furthermore, the reader learns that Sengge's writings feature many ambiguous expressions that could be understood in more than one way; this is mentioned as one of the reasons why Judy, the American scholar, wishes to meet him. ${ }^{79}$

In the stories, all the artists are depicted as actively practising their artistic activities. Often they are deeply devoted to their art: Pedron expresses her emotions with her lute and the bard continues to sing the stories of Gesar even when expressions of traditional Tibetan culture are oppressed by the PRC. ${ }^{80}$ Connected with these characters is also a kind of motif of making one's own freedom: Sengge appears as not caring what others think of his way of life, Pedron chooses to continue her wandering lifestyle on two occasions, and Wangden escapes home (even though this appears to be the act of a young person seeking adventure and independence more than an artistic move, he nonetheless practises his artistic occupation during his travels with his friends). Thus, even though there appears to be no special or sudden transformative moments of a calling to become an artist, the deep devotion to their art suggests that the characters possess a deep and firm inner calling to it. These stories are artist stories in the sense that the artists are depicted engaging in their craft. In the longer work, Tashi Palden's "rGyud skud steng gi rnam shes", it is also possible for the reader to follow, in the style of a Bildungsroman, the development of the artist in her artistic career from childhood to mature age.

\section{RELATIONS BETWEEN THE ARTIST AND SOCIETY}

The stories discussed in this article also contain scenes which depict the relation of the artist and society, or different attitudes of various people towards the artists and their art. The nature of the relation of the artist and society may also undergo changes in a single story, given the presence of various kinds of policies towards culture. It has to be understood that the official policies and attitudes of people may be widely different; hence, the relation between artists and

\footnotetext{
76 Tshe ring don grub 2002: 92-95. A beautiful Tibetan thangka of the goddess Sarasvatī can be seen in the catalogue of the "Wisdom and Compassion: The Sacred Art of Tibet" art exhibition (Rhie \& Thurman 1991: 135), which took place at the Asian Art Museum in San Francisco.

77 Mention of this title can be found on the first page of Tsering Dhondup's novel (Tshe ring don grub 2002: 1). I have here made use of a translation for bre ser 'brong given in an article about Tibetan proverbs by Sørensen and Erhard (2013: 5-6, 10), which featured a proverb found in Don grub rgyal's short story "'Brong stag thang" ("The Plain of the Wild Yak and the Tiger").

78 Tshe ring don grub 2002: 95: "khang pa di'i nang seng ges khong khro'i ngang brtsams chos mang po legs 'grub byung bas kho rang khang mig 'di la zhe 'dang khyad par ba zhig yod par ma zad".

79 Tshe ring don grub 2002: 44-46. In the novel, this ambiguous quality of Sengge's writings resulting in difficulties of understanding and translation is expressed with the words: "go ba nyis ldan dang tha na sum ldan gyi tshig", or "words which have two or even three meanings" (Tshe ring don grub 2002: 45).

80 In Dhondup Gyal's story, the times when the bard cannot sing openly outside but sings instead inside his house could be thought to be during the Cultural Revolution in the PRC. According to Smith (1997: 541-546), the oppression of Tibetan culture during the Cultural Revolution was based on Mao's idea "to create the new by first destroying the old": old culture was then viewed as one of the "four olds" which would need to be destroyed.
} 
society cannot be characterized in clear terms, often containing various aspects and nuances that may even be contradictory by nature. Tibet has been under the rule of the People's Republic of China since the 1950s and its rule and policies have shaped the nature of the society. While in the stories the artists are not depicted as working in isolation from society, it has an effect on their life and career.

In Dhondup Gyal's "Sha dang rus pa'i brtse dungs", the relation of the artist and society appears to be the least problematic of all the stories discussed here. Since Wangden the thangka painter is presented as already being at an advanced age when he relates the story of his younger years to the narrator, the part describing how he learned to paint and then travelled around Amdo would have been during the time of the traditional society before Tibet was occupied by the Chinese and fell under Communist rule. In this story, the artist character does not face difficulties or oppression when it comes to practising his art; painting is depicted as an activity by means of which he earns his food and living. However, the way in which Wangden and his friends become victims of robbers while on their journey suggests that the reality of law and order was not so good then.

In Dhondup Gyal's "sGrung pa", the relation of the Gesar bard and society shifts from more positive attitudes in the beginning towards highly negative and oppressive attitudes described in Part 3, where the artist is severely limited in his actions and then gets seriously injured in a struggle session and after some time passes away. ${ }^{81}$ This story can also be discussed as an artist story, since its main character has the profession of a storyteller. Even though it does not depict his development as a bard, it tells about the difficult external conditions and their tragic outcome. Thus, this story is socially critical and draws attention to an important aspect of artist life in the PRC, namely, the need to take into consideration the political situation when practising art, in order for difficulties not to arise. Telling about the sufferings experienced during the Cultural Revolution became acceptable under the more lenient policies in the PRC around the beginning of the 1980s. Since the story tells about the sufferings of a character or possibly even the fate of a real person whom the writer knew, ${ }^{82}$ it can be interpreted as belonging to the genre of "literature of the wounded", which started to be written in China after the end of the Cultural Revolution. ${ }^{83}$ Placing it in that genre does not exclude it, however, from also being analysed as an artist story.

Dhondup Gyal's "sGrung pa" is told by a first-person narrator. Through the narrator's perspective and his dialogue with the bard, the reader hears about happier times in the life of the bard, when he could freely practise his art of singing Gesar stories, and also difficult times, probably during the Cultural Revolution, when Tibetan traditional and folk cultures were severely restricted. The old bard characterizes himself as "a person of both the new and old age" (bskal pa so rnying gnyis kyi mi) ${ }^{84}$ With this he apparently refers to his lived experience of both the time before the arrival of the Chinese Communists in Tibetan areas in the 1950s and after that. In Tibetan-language publications published inside the PRC, Tibetan society is characterized with the terms "new society" (spyi tshogs gsar pa) and "old society" (spyi tshogs

\footnotetext{
81 Don grub rgyal 1981: 45-46.

82 See n. 10 about Stoddard (1994: 828) explaining the real life inspiration for Dhondup Gyal's short story. 83 See Innes Herdan's research work on modern Chinese literature for the beginning of "literature of the wounded" in China; it contains information about an influential work of this genre, Lu Xinhua's 1978 short story "The Wounded" (Herdan 1992: 130-132). See also Wang (2000a: xxiv; 2000b: 53-54).

84 Don grub rgyal 1981: 41.
} 
rnying $p a$ ), the first referring to the society that had undergone socialist transformation and the second to the traditional Tibetan society. ${ }^{85}$

In the first part of Dhondup Gyal's story, the narrator has come to visit his native village. Seeing a particular pine tree evokes childhood memories related to the bard, who used to sing the Gesar epic there while people gathered around to listen. These memories of the bard are positive, and the narrator characterizes the atmosphere as joyful, telling that only the "sound of singing and laughter" were heard.$^{86}$ In the second part of the story, the narrator visits the house of the bard, where they talk with each other. Although their main topic of discussion focuses on the present restrictions on cultural activities, the bard also reminisces in a positive way about the years following the "liberation" (bcings 'grol) but before the story time - a time which he views as characterized by equality between people. Then, he had been able to engage in his traditional art of storytelling and his importance as a folk artist was acknowledged by officials and government workers, who had called him "the bard of the people" (mi dmangs kyi sgrung pa) ${ }^{87}$ The expression "liberation" refers to the period when the Chinese Communists came to rule the region; from another viewpoint this is viewed as "occupation" ${ }^{88}$ The bard's reminiscences describe the situation of Tibetan folk culture and art as being better in the 1950s, compared to the contemporary moment when he was speaking with the narrator, which could be located during the Cultural Revolution. ${ }^{89}$ In addition to the new cultural policy (srid jus) forbidding singing or telling stories, the bard points out that religious activities such as reciting religious prayers are not allowed. ${ }^{90}$ These kinds of restrictions match those seen during the Cultural Revolution, when there occurred widespread destruction of Tibetan culture. In his Tibetan Nation, Warren W. Smith (1997: 541-562) explains that the Cultural Revolution was ideologically based on Communist ideas about the need to destroy the old, so that the new could replace it. ${ }^{91}$ In the context of Tibetan culture this meant that the Red Guards aimed to destroy anything representing the old culture. This included monasteries, religious paintings, religious and other old manuscripts and sculptures, and mani walls. Furthermore, many activities connected to the traditional culture of the Tibetans were not allowed. Smith (1997: 545) characterizes the ideological atmosphere in those times, "All 'reactionary' Tibetan customs, traditions, songs and dance, even language were to be replaced by 'progressive, socialist' Chinese styles". Due to the references to restrictive policy, the second part of "sGrung pa" is probably set sometime during the years 1966-1976.

The bard's words to the narrator reveal that he does not take seriously the injunction to refrain from telling stories, but holds it merely as oppressive speech:

\footnotetext{
85 For an explanation of these terms, see Tsering Shakya 1999/2000: 316-317.

86 Don grub rgyal 1981: 37.

87 Don grub rgyal 1981: 41-42.

88 Qinghai had been under the power of Ma Bufang before the arrival of the Communists, as is mentioned in research by Benno Weiner $(2012: 58,425)$ on the recent history of Amdo. He explains that the "liberation" of Qinghai was proclaimed already in 1949 but was not actually complete until the first half of the 1950s (Weiner 2012: 131-151).

89 Since we are looking at a short story, the exact years when the different descriptions in the narrative are located in time are not indicated explicitly.

90 Don grub rgyal 1981: 40-41.

91 For more information on the Cultural Revolution in the People's Republic of China, see Hsü 1990: 689-706 and Tsering Woeser's gSar brje, translated from Chinese into Tibetan by Dolkar and published as an e-book in 2013. One of the chapters in Tsering Woeser's book tells about the destruction of religious artefacts and scriptures by the Red Guards that took place at the Jokhang Temple in Lhasa. It contains several photos taken by Tsering Dorjee, the father of the author of the book, that document scenes of destruction such as the burning of religious objects (see Tsering Woeser 2013: 118-196).
} 
sgrung bshad mi chog zer ba de gnas lugs med pa'i btsan gtam kho na red/ nga rgad po gtam phar bshad tshig gi brda dag dus/ tshig tshur bshad don gyi phugs go dus nas bzung/glu a la la mo blangs nas tha la la mo then pa yin/gzhon so dkar dus nas rgas mgo dkar bar du sgrung ma bshad zer ba'i mi zhig byung ma myong/(Don grub rgyal 1981: 41)

Saying that it is not allowed to tell stories is merely baseless, oppressive talk. I am an old man, and since the time I was able to say something and since I was able to understand the meaning of words said to me, I have been singing the songs a la la mo and tha la la mo. Since my teeth were white in youth to the time my head was white, not a single person has said to me that I should not tell stories.

It can be understood here that despite the ban on singing the epic, the bard continues his performances singing inside his own house. This leads to tragic consequences which come to the knowledge of the narrator in the third part of the story, when he visits the village again after three years have passed. An old woman tells that in the time he had been away, the bard had to participate in a struggle session where he was the victim of a violent attack. Due to the severity of his injuries he could not recover but tragically died. Accused of being "anti-reformation for telling stories" (sgrung bshad nas gsar brjer ngo rgol byed mkhan), ${ }^{92}$ the bard had become the victim of what is called in the story "the campaign of eradicating deities, demons, evil spirits and obstacles" (lha 'dre gdon bgegs' dbyung ba'i las 'gul)..$^{93}$

In this story, the villagers love to hear tales even when their telling has been prohibited. However, the state of society and people's behaviour has been regulated and influenced by the policies that prevailed at that time. Research on Tibetan history explains how during the decade of the Cultural Revolution in the People's Republic of China, many people had to suffer in struggle sessions; the accused were publicly criticized and suffered violent torture. Not only people considered to represent the old, traditional culture, such as religious practitioners, but also people who had previously been prosperous, like rich landowners and aristocrats, became targets of criticism and experienced problems. ${ }^{94}$

The fourth and last part of the story describes a point after some cultural liberalization has taken place, probably near the end of the 1970s or early 1980s. It reflects how the attitudes towards Tibetan traditional folk culture have turned more positive than during the troubled times of the preceding decades. Although the old storyteller is no more, his memory is openly respected by the people. The first-person narrator makes homage to the memory of the bard:

nga sgo kha nas gus stabs kyis langs te a khu sgrung pa la mya ngan 'di ltar zhus "a khu sgrung pa lags/ 'mi bzhi tshogs khag' gras kyis khyed la mnar gcod btang ste dal 'byor gyi mi lus rin chen 'jig par byas kyang/ khyed gyi sgrung gi lang tsho de dpyid gsum gyi me tog ji bzhin bod mi dmangs kyi sems la shar yod lags" (Don grub rgyal 1981: 47)

92 Don grub rgyal 1981: 45

93 Don grub rgyal 1981: 45. As already mentioned, no exact years of fictional events are given in Dhondup Gyal's story, and in the case of fiction there is no need to point them out. However, the characteristics and period of some developments might differ in Amdo from those in Central Tibet. For example, Weiner (2012: 405) mentions the occurrence of struggle sessions in Amdo already during the latter part of the 1950s, which is several years before the beginning of the Cultural Revolution (1966-1976). However, the way in which in the fourth part of the story the narrator accuses "those having associated with the Gang of Four" of the torture which the bard had to suffer (Don grub rgyal 1981: 47) could suggest that the description of the restrictions (in the second part) and then the torture and death of the bard two years after the narrator last met the bard (related in the third part) all referred to events during the Cultural Revolution. As described in Immanuel C.Y. Hsü's (1990: 820) The Rise of Modern China, the members of the Gang of Four were, among other charges, accused of crimes against the people during the Cultural Revolution in a trial in 1980-1981.

94 See, e.g., Smith 1997: 402-404; Shakya 1999/2000: 325, 352. 
I stood at the door respectfully and said words of mourning to Uncle Bard like this: "Uncle Bard, although those of the 'Gang of Four' ${ }^{95}$ tortured you and destroyed your precious human body with leisures and endowments, ${ }^{96}$ the youth of your stories, like the flowers of the three spring months, are growing in the minds of the Tibetan people".

Judging from the descriptions in this part of the story, the attitudes of the society and the cultural policies have turned in a more positive direction, and the bard has posthumously regained his reputation and status. Gesar stories are broadcast from a loudspeaker, revealing that the performance of traditional Tibetan stories has again become allowed in public. ${ }^{97}$ Of course, this could not help the old storyteller anymore, but it characterizes the attitudes towards art in the post-Mao times in Tibetan areas.

A story about a folk artist and his sad fate can be held to represent an early stage of Tibetan artist stories. ${ }^{98}$ After all, folk artists have long been known to Tibetans. They were practising their arts in traditional Tibetan society way before the $1950 \mathrm{~s}$, too, whereas Tibetan artists specializing in modern arts started to appear and gain prominence only in the second half of the twentieth century. Dhondup Gyal's "sGrung pa" has two sides: it is a story about an artist and at the same time a socially critical work exposing the problems of cultural workers during a certain stage of history.

In Tashi Palden's novella "rGyud skud steng gi rnam shes", the appreciation and status of the artist character, Pedron, also undergo changes. These changes have a connection to the shifts in political climate and cultural policy. Remarkably, the period of the story ranges from the era of traditional Tibet in Pedron's childhood and young adult life to the Cultural Revolution and then the subsequent years of liberalization in the cultural policies, possibly the 1980 s. However, the narration does not proceed in strict chronological order, but the passages and scenes set in Pedron's youth and elder years alternate. In those passages, which are set in the so-called "old society" (as it is referred to in materials published inside the People's Republic of China), it is possible to find ideas associated with the status of wandering musicians in traditional Tibet. Pedron belongs to a family of wandering musicians. Their status seems much lower than a Western person would tend to expect of such an artistic vocation. While we usually tend to think artists as very unique and special individuals, somehow different from others, Beebe (1964: 41) insightfully remarks that the idea of "uniqueness" of the artist personality has become a stereotype.

In Tashi Palden's novella, Pedron's father prefers to mostly perform locally. The reason for this is that in areas where one's family is not known, a musician's status is equal to that of a beggar. But in the area they are known, people treat them normally and do not consider them as

\footnotetext{
95 See Shakya 1999/2000: 314, 367-371 for information about the arrest of the "Gang of Four" in 1976 and how they were then accused in the PRC about the problematic aspects of the Cultural Revolution.

96 The Buddhist term dal 'byor refers to the eight leisures (dal ba brgyad) and ten endowments ('byor ba bcu); see Tsepak Rigzin 1997: 132, 194.

97 See Don grub rgyal 1981: 46-48.

98 In a completely different cultural context, stories of folk artists have been held as an early stage of artist stories. In her article about Juhani Aho's Muudan markkinamies, Tarja-Liisa Hypén (1992: 14) reports about the interesting views presented in an MA thesis by Terttu Härkönen (1965), namely, that the first stage of artist stories in Finnish literature are depictions of folk artists. Hypén (1992: 16) held Muudan markkinamies (from the latter half of the nineteenth century) to be an early artist story in Finnish literature, although according to her others have paid more attention to its social criticism of the life of poor people in earlier Finnish society.
} 
unclean, like smiths and butchers traditionally considered to be low class. ${ }^{99}$ The story depicts the itinerant lifestyle of Pedron and her father to be such that they receive food and drink from their listeners in exchange for performing. ${ }^{100}$ However, there appears to be a difference between just receiving material benefits from performing and, on the other hand, the risk of becoming considered someone belonging to outcasts and associated with the idea of "pollution", which could happen if they left their own area. ${ }^{101}$ The low esteem in society of Tibetan wandering musicians and performers was noted nearly a century ago by Sir Charles Bell, and his portrayal of the music that these "beggar fiddlers" make is not very flattering: "The young assistants join in the dance, and solicit and collect the alms to the accompaniment of a plaintive whine that is universal and never varies" (Bell 1968: 136).

Another publication published in the 1920s that recounts Tibetan society in the decades before the occupation is Rinchen Lhamo's We Tibetans. This book has a short chapter entitled "Dance \& Song", which describes the style in which Tibetans sing and dance together. Rinchen Lhamo writes that there are not many cultural activities which could be classified as "professional shows", but she mentions "historical dramas". She ends her chapter with an interesting observation:

We have also strolling players, men and women and children, who sing and dance and crack jokes. Such people are looked upon more or less as beggars, like your street musicians. (Rin chen Lha mo 1926: 126)

Although wandering around and being not economically wealthy has connections to the kind of Bohemian lifestyle mentioned by Beebe (1964: 74-79) and discussed above, no such romantic idealized notions existed in the Tibetan society of that time. The novella instead describes the low status of musicians in Tibet during the times of traditional society, pointing to a problem of social inequality. Especially dear to Tashi Palden's heart are "underprivileged characters" (las skal dman pa'i mi sna), who appear to be ordinary people living in remote areas, such as small villages in the countryside. ${ }^{102}$ His decision to depict the life of a folk artist, and especially the part before she is recognized and gains fame, appears to accord with his overall preference to write about persons of a somehow "weaker" social position or section of society. Presenting people with humble origins as heroes and heroines accords well with the idea of creating art for the masses, which is typical of socialist realism. ${ }^{103}$

While "rGyud skud steng gi rnam shes" presents some attitudes and values surrounding wandering folk musicians in traditional Tibetan society, it is interesting to ask whether this characterization of a person as resembling a beggar in terms of their low social appreciation reflects actual past perceptions and the situation of wandering musicians or if the characterization has been influenced by the socialist realist style. In the socialist realist style, depictions of the old society typically emphasize the inequality of persons, ranging from the aristocracy

\footnotetext{
99 bKra shis dpal ldan 1999: 31. In traditional Tibetan society, a belief about "pollution" (grib) was associated with some low-class groups (see Fjeld 2005: 28-29, 47-52).

100 See bKra shis dpal ldan 1999: 24-26.

101 The difference of their treatment in their own area and other areas is characterized in the story with the explanation that in their own area they can drink beverages by "sharing bowls" with others (phor pa mnyam du btsugs) and then, on the other hand, in other areas they are considered by people similar to other beggars (sprang slong gzhan dang 'dra ba'i lta stang las lta stang mi 'dra ba gang yang med pas); see bKra shis dpal ldan 1999: 31. 102 bKra shis dpal ldan 2006b: 38-40. See also Virtanen 2018: 83-84.

103 On socialist realism, see Herdan 1992: 95-97; about its definitions in different periods in the Soviet Union and China, see Su 2000: 65-66, 68, 70.
} 
to those who belonged to the lower classes or were servants. ${ }^{104}$ To present problems such as inequality in Tibetan society before Chinese rule also serves to show the need for social change in those times. In "rGyud skud steng gi rnam shes", the inequality is depicted in the descriptions of Pedron's work in the fortress, where her status is held to be almost the same as that of servants, with the exception that she receives some salary for her work. The social status of folk artists like Pedron does not seem to be depicted as low due to the demands of the socialist realist style, but instead appears to reflect that the profession of the wandering musician was simply not appreciated in traditional Tibet.

The social status of the characters is apparent in both their speaking and behaviour. When Pedron is asked to work as a musician at the fort, her status changes slightly; however, her conditions and treatment remain the same as those of servants, with the difference that she receives a salary (lto phogs). ${ }^{105}$ The differences in the status of Pedron and Namgyal Phuntsog (rNam rgyal phun tshogs), the young lord, are demonstrated in their behaviour: Pedron gets very nervous and even trembles when he suddenly comes to see her. Even when he requests her to sit down, she cannot help but remain standing out of respect. ${ }^{106}$ It turns out that Namgyal Phuntsog would like to learn to play the lute, and after he gains reluctant permission from his stepfather, Pedron starts to teach him. The way in which the lord of the fortress comments about lute-playing to his adopted son shows that he does not appreciate it much. Namely, he does not hold it as something beneficial for a person of higher position. To illustrate his attitude, he recites a traditional saying: "The lion who stays on the snow is a lion. A lion who descends to the valley is an old dog." 107 As a result of playing music together, Pedron and Namgyal Phuntsog develop a secret romantic relationship. The inequality of their social status again becomes evident, as their relationship is not tolerated and brought to an end. Pedron, who is pregnant, must leave the fort. ${ }^{108}$ Although Namgyal Phuntsog is depicted in a sympathetic light as a kind person, he cannot oppose the orders of his stepfather. Innes Herdan (1992: 96-97) has described the characterization typical of social realism as portraying characters as either good or bad. In an earlier Tibetan novel, dPal 'byor's gTsug g. yu, the characterization of which can be viewed as influenced by socialist realism, the characters belonging to aristocrats were depicted in a negative light. ${ }^{109}$ In Tashi Palden's novella, the character of Namgyal Phuntshog, despite his aristocratic family upbringing, is depicted as pleasant. But while his character does not seem to match the ideals of characterization in socialist realism, the way he and his behaviour

104 The idea of inequality and the need to correct that situation are connected to the idea of class struggle and the aim of improving the situation of ordinary people, which play an important role in the theoretical views of socialism. See Mathewson 1975: 1, 144. Mathewson writes about heroes in literature in the Soviet Union, where the theory of socialist realism originated before being absorbed into Chinese literature.

105 bKra shis dpal ldan 1999: 31. The idea that the servants in the fictional novella would not receive a salary is merely based on the words of the narrator in the novella: "...pad sgron nang bzan dang mi 'dra bar lto phogs len rgyu yod/" (bKra shis dpal ldan 1999: 31). In his article on servants in traditional Tibetan society, Okawa (2017: 288-289) describes the situation and treatment of servants (nang zan) as varied in different households; in some cases, they were given grain, which they could cultivate on land which was not owned by them. It is difficult to say whether receiving grains for cultivation could be considered as salary, however, interpreting the fictional passage, it sounds that Pedron's social status in the fortress was slightly better than that of the servants and she was thus not considered as a "slave", but a hired worker.

106 bKra shis dpal ldan 1999: 35-36.

107 bKra shis dpal ldan 1999: 40-41: “seng ge gangs la bsdad na seng ge yin/ seng ge klung du bab na khyi rgan yin".

108 bKra shis dpal ldan 1999: 76-87.

109 See Virtanen 2016: 494-499. 
are described could be called realist, as he also has to adjust to the conditions and restrictions of his social environment. Generally, realist writing is considered such that the world and people are depicted as a description of real life, even though it is understood as fiction. ${ }^{110}$ In my opinion, the style of "rGyud skud steng gi rnam shes" and its characterization could be described as realist. Choosing the term "realist" over "socialist realist" is supported by the novel's relatively nuanced characters with various kinds of qualities, which are not completely positive or negative in nature. Tashi Palden's way of writing possesses a certain straightforward quality and lacks unnecessary complexity, which lends a certain admirable flavour of "honesty" and directness to his fiction; his works are generally free from unnecessary exaggerations and fabrications. Also, his main literary work, the novel Phal pa'i khyim tshang gi skyid sdug, can be considered characterized by realist style. ${ }^{111}$ Reading Tibetan modern literature, it is possible to notice a stronger influence of socialist realism in the 1980s; this later weakened in the 1990s, when more works started to appear in a realist style.

As described already above, the novella "rGyud skud steng gi rnam shes" also contains some depictions of a time when there were restrictions on cultural activities and Pedron had to leave her lute with a certain unit and go do agricultural work. This period, when a folk artist could not continue to play her music, seems to correspond to the time in Dhondup Gyal's "sGrung pa" when storytelling was not allowed. In "rGyud skud steng gi rnam shes", there are suspicions about Pedron's "class and standing" (gral rim dang lang phyogs), since it was known that she had for some time worked at the fortress and had had a relation with the adopted son of the lord of the fort. ${ }^{112}$

The description of Pedron's later years reflects a change of attitude in the society towards folk artists and folk art. In her old age - now a grandmother - Pedron is recognized as a folk artist and gains fame when she performs in Lhasa in a cultural competition. The developments leading to her recognition and fame are of interest to us and I shall sum up them shortly here. Her invitation to the show in Lhasa follows an accidental meeting with some travellers in a mountain pass, for whom she plays and sings. One of them takes a special interest in her music and thinks that she could be recognized as a professional folk artist (dmangs khrod sgyu rtsal pa). ${ }^{113}$

When Pedron performs on stage in Lhasa, her performance is shown on television and she becomes famous. People from the cultural office also come to visit her, and among this group is a woman whose words reveal an appreciating and supportive attitude towards folk culture. Namely, she regards folk culture as "priceless inherited wealth" (rin thang bral ba'i shul bzhag rgyu nor) and folk artists as "the managers of inherited wealth" (shul bzhag rgyu nor gyi gnyer $p a$ ). She says that the folk artists have the "key for handing the inherited wealth to the next generation and therefore it is necessary to appreciate and take care [of them]". ${ }^{114}$ The dramatic

\footnotetext{
110 For an explanation of realism, see the dictionary of literature by Yrjö Hosiaisluoma (2003: 767), who remarks that one way of understanding realism is to understand it as not bound to a certain time period; he tells about the views of Auerbach presented in his Mimesis, and how realist features can be found in literary works from different time periods. Thus, one can also describe as realist Tibetan works which reflect the real state of the world in fictional narratives.

111 See Virtanen 2018: 61, 68-69, 81.

112 bKra shis dpal ldan 1999: 48.

113 bKra shis dpal ldan 1999: 10-11.

114 bKra shis dpal ldan 1999: 108: "dmangs khrod sgyu rtsal ni rin thang bral ba'i shul bzhag rgyu nor zhig yin pa dang khyed tsho lta bu ni shul bzhag rgyu nor gyi gnyer pa rnam dag cig yin la mi rabs rjes mar shul bzhag rgyu nor brgyud sprod bya rgyu'i lde mig de khyed tshor yod pas dngos gnas mthong chen dang lta skyong bya dgos kyi red".
} 
increase in appreciation of folk music and folk artists during the main character's older age presumably corresponds to the period after the more liberal policies of the post-Mao years.

Last I shall discuss the relation of the writer Sengge and the surrounding society in Tsering Dhondup's novel sMug pa. Different kinds of attitudes towards a writer's work are reflected in the story. Some of them are individual attitudes, while others appear to be more on the level of society and the ruling system. The novel starts with Sengge speaking with a friend about the difficulty in finding a publisher for his new novel. Sengge writes mainly in Tibetan and is described as cherishing and being attached to his own Tibetan language. ${ }^{115}$ Their discussion gives the impression that it would be easier to find a publisher for a manuscript in Chinese. However, the novel is published in America in an English translation and gains enthusiastic reception there. ${ }^{116}$ For a writer, it is hard to remain enthused about continuing to write if there are problems in getting published, and this is the case with Sengge, that the society in which he himself lives is not very supportive of his writing. Erhard (2019: 227-230) insightfully discusses these problems, interpreting them in the light of "hegemonic power", which works in favour of "the dominant culture" - namely, Chinese culture. In general, however, for Sengge to have become an educated individual with skills of reading and writing, one has to acknowledge the role of society in providing proper schooling for children.

Another novel by Tsering Dhondup, Rlung dmar 'ur 'ur, also lacks mention of any publisher. After researching this book, Erhard (2013: 114) explains that it was published by the author himself. He describes the obstacles involved in finding a publisher and also the hardships the author experienced after its publication. The relative difficulty for writers to publish in Tibetan is mentioned by Tashi Palden in an essay in which he speaks about his experiences and views as a writer. Noting that the number of Tibetan readers is very small, ${ }^{117}$ he explains how he nevertheless wishes especially to write for them.

Tsering Dhondup's novel sMug pa also describes some individuals' admiring attitudes towards Sengge and his work. One of these persons is Judy, who takes so much interest in his literary work that she translates his novel into English and wants to see the area where the stories are situated. ${ }^{118}$ Another is a young man who has travelled from some distance in order to meet the writer and get his comments and advice about a short story that he himself has written. However, the comments that Sengge makes about the short story written by this young man are quite meagre. Sengge's friends are present and most of the time is taken up by drinking beer. ${ }^{119}$

The image of fog is central in the novel, being indicated in its title and repeatedly mentioned in the story. The fog most often appears as a concrete image - that is, the weather condition in connection with descriptions of the scenery, such as grasslands enveloped in fog. In some places the fog is also described as "cold". ${ }^{120}$ Thus, the reader is led to think that fogginess could

115 In Tsering Dhondup's novel, the fictive writer Sengge's attachment to Tibetan language becomes apparent in other regards, too: for example, in his attitude to the language choice and educational preferences of his Tibetan ex-girlfriend, a painter, who speaks all the time in Chinese (see, e.g., Tshe ring don grub 2002: 85-86). In the dialogue, the words of this Tibetan girl are written in Chinese, as are the words of Sengge when he addresses her. To most of the other characters Sengge speaks Tibetan; the only other exceptions are Chinese to the police and a couple of words in English to Judy, breaking from their normal communication in Tibetan because Judy speaks it fluently.

116 Tshe ring don grub 2002: 1-3, 46.

117 bKra shis dpal ldan 2006b: 37-38.

118 Tshe ring don grub 2002: 44-46.

119 Tshe ring don grub 2002: 7-14.

120 Tshe ring don grub 2002: 92. 
be a characteristic of the climatic conditions of the place where Sengge lives. The fog is also described as having an aesthetically pleasing aspect: Sengge's ex-girlfriend Metog, who is a painter, goes out to capture fog in her paintings.

However, when the fog appears again in the last scene of the novel, it transforms from external fog to a metaphoric fog. Sengge and Judy are at the airport in Beijing, about to leave for America. Their flight has been delayed because of thick fog, which finally clears. Suddenly, Sengge is arrested by two policemen who look familiar. The fog appears again between Sengge and Judy when the policemen are dragging him away from her. This time the text characterizes it as "a bit of fog, unknown whence it appeared" (gar yong mi shes pa'i smug pa dum bu zhig). ${ }^{121}$ The appearance of fog between the two characters is not likely a weather condition, but a symbolic element.

The reason for Sengge's arrest can be understood from the words of the policemen. He is accused because of some undesirable aspects of the books that he donated to a library before leaving his homeland in Amdo. The content in these is not political; the police identify the reason for his arrest to be "the spreading of erotic or pornographic materials" (chags sred kyi dngos rdzas 'grem spel byas pa'i nyes ming); they mention as examples such books as Western Sports (Nub gling gi mi lus sgyu rtsal) and Lady Chatterley's Lover (Lha lcam khra the le'i $\left.d g a^{\prime} \operatorname{rogs}\right)^{122}$ by D.H. Lawrence (1885-1930). ${ }^{123}$ Thinking about the final scene of $s M u g p a$ and the arrest of the writer in the airport, one wonders how the possession and donation of such books could lead to arrest in modern times. These objects could have been regarded as "decadence and cultural 'pollution' from abroad", to use one of the descriptions of controlled objects mentioned by Perry Link in his Uses of Literature, which deals with literary life in the People's Republic of China. He also explains how the concept of "decadence" can have a connection to liberalism, and he notes that during some campaigns in the 1980s in the PRC, "to watch pornographic videotapes" was considered "improper behaviour" (Link 2000: 59, 62). The reasons for Sengge's arrest are not directly linked to his own artistic work. Although the arrest of a writer suggests a restrictive and suppressive attitude towards artists, the stated reason of his arrest is not tied to his own literary work; it thus appears trivial and made up. Link explains that artists in China were sometimes accused of less important things than the actual core issue:

Another common use of euphemism was to charge a writer or artist with an offense other than the one that really mattered. The advantage of this tactic was that it could censor an offensive viewpoint without drawing increased public attention to it. The more truth a viewpoint contained, the more important it was to draw attention elsewhere. (Link 2000: 90)

121 Tshe ring don grub 2002: 206.

122 Tshe ring don grub 2002: 204. The two policemen speak Chinese, but their words in the novel are also given in Tibetan in brackets.

123 According to research literature and other sources, D.H. Lawrence's Lady Chatterley's Lover was first published in 1928. For the circumstances and information of its writing and publishing, see Hyde 1990: 6-7; Gertzman 1989: Section 1; and Roland Gant's "Publisher's Note" and "A Foreword" by Frieda Lawrence in Lawrence 1972: v-Xv. It has appeared in both censored and complete editions; its publication in a complete version led to a trial against its publisher, Penguin Books, in 1960 in England (see Gertzman 1989). In an introduction to a volume on this trial, Hyde (1990: 1) explains that it mainly concerned whether the book was obscene and whether it would have an immoralizing effect on its readers. In the end, Penguin Books was exonerated of all charges, and it was allowed for the book to be sold in its complete edition on the British market. For more on this, see Hyde 1990: 1-3, 6-10, 14, 42-44. 
There are some hints about the impending arrest in the story: when Sengge and Judy are visiting Sengge's family, they become aware of two policemen watching them. The two policemen appear to be the same ones that had been watching them earlier in Amdo, and it is also noted that they "resemble the two policemen that had several years before been led by Metog's father". ${ }^{124}$ In this context, it is told how Sengge had once been arrested much earlier at school; Metog's father, who was in a leadership position, had sent two policemen after Sengge for bullying Metog, who was in a Chinese language class. ${ }^{125}$ Due to the fact that two policemen, a Tibetan and a Chinese, started to watch Sengge and Judy after Metog moved out of Sengge's house, ${ }^{126}$ the reader might start to wonder whether, aside from giving away materials deemed pornographic or erotic, some personal grudges may have been involved in the arrest. In one passage, the policemen themselves are described as getting irritated when checking Judy's passport at Sengge's house, when they promise "not to let" Sengge and Judy "remain in peace". ${ }^{127}$ Such motivations remain ambiguous, however; it could even be said that the actual explanation for understanding why the character Sengge becomes arrested remains metaphorically "foggy" in the novel.

On the basis of the text alone, we cannot say for certain what the writer is wishing to convey with the fog, namely, whether it has a metaphorical meaning or really only refers to actual fog in the storyworld. One way to interpret the fog, however, would be to understand it as characterizing some sort of atmosphere whose nature cannot be clearly pinpointed, or as affecting visibility and making it impossible to understand clearly. It is interesting to note in Perry Link's research that he uses the adjective "foggy" in relation to explaining the nature of literary control in China. He writes: "Every Chinese writer and editor had to be his or her own judge of the foggy and treacherous political-literary "weather"' (Link 2000: 56). And as an explanation for the changes in the so-called "weather", Link (2000: 77) explains that it depended on the minds of those in power at different times and could thus undergo changes.

Jampa Tsultrim also suggests some interpretations on this element in the novel. He draws the reader's attention to the way in which Metog views the fog as something aesthetically beautiful, whereas Sengge dislikes it. This Tibetan critic also gives both environmental and other interpretations for the fog, mentioning "the fog of the society which is polluted by corruption, deceit, etc.", "the people who never wake", an "obstacle to the successful achievement of wishes", and "something which covers the environment". ${ }^{128}$ Erhard (2019: 235-237) also discusses fog, insightfully interpreting it as a "metaphor" for the "cultural hegemony and social domination" experienced by Tibetans living under the rule of the PRC. Erhard supports his reading with several translated passages from the novel with mentions of fog. Tsunpo Dhondup (bTsun po don 'grub 2014: 221-224) has also discussed the many occurrences of fog in the novel and the scene at the airport. He views the use of this image as a modernist feature and stresses its significance for the novel, characterizing its function as representing something which "opposes". ${ }^{29} \mathrm{He}$ discusses how the fog cannot be interpreted as only illustrating the outside environment, but also represents meanings

\footnotetext{
124 Tshe ring don grub 2002: 116, 177, 204.

125 Tshe ring don grub 2002: 116. It is described in the novel how Sengge had forced Metog to wear a paper hat and paraded her around the school area with her hands behind her back.

126 Tshe ring don grub 2002: 181-182.

127 Tse ring don grub 2002: 182: "nged tshos khyod gnyis bde bar sdod du mi 'jug". The words of the policemen are again first written in Chinese and then translated into Tibetan inside brackets.

128 Byams pa tshul khrims 2011: 206-208.

129 bTsun po don 'grub (2014: 222-223): “de yang <<smug pa>> yi nang gi “smug pa” yis 'gal zlar gnas pa' $i$ don dag cig mtshon 'dug".
} 
related to the "mind of the protagonist" (mi sna gtso bo'i sems khams) and "people in the external world" (phyi rol gyi mi rnams; bTsun po don 'grub 2014: 224).

It could well be that the novel is meant to remain ambiguous, such that no "certain meaning" can be pointed out and everything is purposefully left as if "covered by fog". This kind of ambiguity could be needed when writing in a society lacking freedom of speech, where a person's opinions can lead to arrest and imprisonment. In a way, the fog which covers the grassland and its people - and forms between Sengge and Judy - could also represent how difficult it may sometimes be to understand contemporary Tibetan literature. Given that writing is expected to conform to certain norms and some topics are not desired, ${ }^{130}$ in some cases the intended meaning behind a text could be seen as obscured and impossible to discern in an accurate and reliable way, although various interpretations and guesses could be suggested.

To summarize the discussion on artists and their relation to society, it is possible to observe in the stories different types of influence and attitudes. We saw how official policies and people's perspectives could vary greatly, even being opposite to one another. Some common features can be found, such as when two stories depict the same period of time; similarities in depictions are likely due to the demands of realism. Especially when reflecting real historical conditions, expressions and performances of art were depicted as restricted and oppressed during the Cultural Revolution, compared to those stories set before the occupation and Communist rule. For example, Dhondup Gyal's "Sha dang rus pa'i brtse dungs" describes how thangka painters and statue-makers travelled around, practising their art and living from it, while Tashi Palden's "rGyud skud steng gi rnam shes" tells how musicians and performers could freely wander, dancing and playing music. While the appreciation of wandering musicians appeared to be low during the time of traditional society before the 1950s, stories depicting artists after some liberalization of cultural policies around the 1980s and afterwards reflected both positive attitudes towards folk culture and restrictions towards a writer who could not travel abroad freely. Thus, even though the attitudes surrounding an artist's career from the side of society were of many different kinds, in most stories, Tibetan society and/or the various policies and cultural tendencies of the PRC since the 1950s had a notable influence, either positive or negative, on one's artistic activities. Accordingly, Tibetan artist characters were not depicted as special individuals creating art outside society or in isolation. Even if the characters sometimes may have wished to do this or even tried to act independently, they were still affected by others or by the policies of the state, which they could not escape.

\section{SUMMARY AND CONCLUSIONS: TIBETAN ARTIST STORIES}

In the Tibetan works discussed here, the artist's connection to society plays an especially important role. The works not only concentrate on the individuals and their unique development, but their artistic work is mostly dependent on the socio-political situation. In Dhondup Gyal's story about the thangka painter, the role of the society is not stressed much; in this work, the painter does not become an artist due to some individual realization or "calling to become an artist", but inherits the profession from his father. In the People's Republic of China, including the Tibetan areas where these works were produced and are situated, the role of art is generally connected

130 The exile Tibetan website Phayul published some years ago a picture of a Tibetan writer who had received a prison sentence because of his book The Restless Himalayas, even though it was unpublished. See "Gagged by China, Tibetan writers find voice in Norway" (Phayul 2012). 
to the idea of serving the people and society, and in a society with a Communist ideology, art is not thought to be completely independent from non-artistic considerations. There is a strong connection between art and society, as well as art and politics.

Only one of the works discussed here, "rGyud skud steng gi rnam shes", is clearly a developmental story of an artist, but here as well the development and practice of art, and the reception of and attitudes towards art, are strongly dependent on society and the political situation. At the same time, this is a socially critical work discussing the life of those people whose status were low in traditional Tibetan society. Dhondup Gyal's story about the thangka painter also contains elements of an artist's development, but here the love between parents and children arises as a more prominent theme. Thus, the Tibetan works discussed here do not centre solely on depictions of an artist's inner development, but they are nevertheless clearly stories about artists. Judging from most of the works here, the conceptions about artists, as well as the roles they play, do not appear as romantic or idealized, as is typical in Western stories of artists. In sMug pa, however, the portrait of a Tibetan intellectual and writer bears some resemblances to the artist type found in the Western Bohemian tradition. Considering the significance of the society and its influence - either negative or positive, supportive or suppressive - on the artist characters in the stories, depiction of these aspects could be regarded as one of the general features of Tibetan artist stories.

One feature that the stories have in common is the motif of freedom, which is expressed in different ways. Even though the surrounding society depicted in the stories has an influence on the artists in one way or another, all of these characters assert their own freedom or try to find it. Sometimes this leads to problems and oppression, as seen in two of the stories. The thangka painter Wangden escapes from home as a youth, the lute player Pedron wanders around on performing trips, the bard Gephel tells Gesar stories at his home even though it is prohibited, and the writer Sengge behaves and thinks in his own way without caring much about the opinions of others. The motif of freedom can also be found in some Western artist stories, such as at the end of Joyce's Portrait of the Young Man as an Artist.

In two of the works, art is passed on through the family lineage. In Tashi Palden's "rGyud skud steng gi rnam shes", Pedron learns musical skills from her father; in Dhondup Gyal's "Sha dang rus pa'i brtse dungs", Wangden learns to paint from his father. That there is no particular description of a special, sudden moment of the artist realizing his or her "calling" or becoming "consecrated" by some kind of "higher power", and instead the profession is naturally inherited from a parent, could be regarded as one of the generic features characteristic of some Tibetan artist stories.

When we compare the different works discussed above, the relationship between the artists and the society is not depicted unidimensionally; it can vary, and the perceptions of art and an artist's work can range from highly positive and appreciating attitudes to negative ones. In Dhondup Gyal's "sGrung pa", the main character suffers actual suppression and torture because of his traditional Tibetan profession as a storyteller. The story depicts the cruel mistreatment and violence as part of a certain time period, namely, the Cultural Revolution; before that the character had been treated as the "bard of the people", and after that his memory is respectfully kept alive and Gesar stories are heard again.

The attitudes towards art and artists also vary inside single works. In Tashi Palden's "rGyud skud steng gi rnam shes", Pedron and her father's status in the traditional society as musicians in the period before the occupation could be understood to be near that of a beggar, at least 
in those areas where their family is not known; nor are the years of the Cultural Revolution conducive to artistic practice, when her lute is taken away and she has to do other work. Later, however, Pedron can sing and play music again, and she wins recognition and fame as a folk artist, reflecting the interest of the Cultural Department and the media's positive and supporting attitude towards art and artists.

Tsering Dhondup's novel $s M u g$ pa is not an easy work to interpret. Indeed, it appears to be constructed in such a way that it remains ambiguous. The arrest of the writer character in the end can be viewed as negative and suppressive, but it is not directly shown whether the arrest had anything to do with Sengge's artistic work or his being an artist. Because the reason given in the novel concerns the possession and donation of materials deemed erotic, the reader is led to ponder the possibility of other "underlying" reasons; however, there are no clear clues. The reader could suspect the arrest was linked to his writings or his lifestyle, or that it was simply due to some individual grudges.

While this work depicts an artist and intellectual that to some extent resembles the Western idea of a Bohemian artist, it has to be stressed that there are also crucial differences, such as the main character's concern for Tibetan language. Features associated with Bohemians are thus connected to a new Tibetan cultural context. Sengge does not appear as the traditional ideal of a scholar, often monastic, but a new kind of contemporary Tibetan intellectual whose behaviour and thinking are quite open-minded and free from conventions. Although he has a new Western girlfriend and tries to leave his homeland in Amdo for her country, this character is not depicted as preferring some other culture over his own; his cultural identity can be said to be Tibetan, judging from how he expresses himself and writes in Tibetan, and how he is concerned about the education of Tibetans in their own language. The novel depicts a kind of intellectual who has risen from the ordinary background of a nomad family, which has become possible in these modern times when education has become possible for children from ordinary backgrounds.

Although only one of the stories, Tashi Palden's "rGyud skud steng gi rnam shes", is written in the genre of Bildung as a developmental story of an artist; all the stories discussed here tell about an artist's life, and the artist character occupies the main role. Therefore, it can be said that these works can be characterized as artist stories, and it is possible to speak about artist stories in a Tibetan context.

The stories discussed were all written in Tibetan in areas currently under the rule of the People's Republic of China. It is important to bear in mind that it is not possible to write just anything one might wish in a society under Communist rule, where art is not free from serving society but ideally needs to benefit it. To gain more of an understanding about the situation of real artists and the effect of the changing political situation in the PRC and the Tibetan plateau on their creative activities and conditions, it is important to pay careful attention to news related to the cultural life and personalities from the region. While such an analysis of the current situation of real artists is outside the scope of this article, one can note how many creative works of literature and culture are continuously published in Tibetan areas under Chinese rule. The existence of current publications written in Tibetan and about Tibetans and their lives shows that Tibetan culture is alive, the creative work of writers is continuing, and new artistic developments are taking place. 


\section{REFERENCES}

Abel, Elizabeth, Marianne Hirsch \& Elizabeth Langland (eds) 1983. The Voyage In: Fictions of Female Development. Hanover, NH: University Press of New England.

Barnett, Robert 2013. Introduction. In: Tsering Woeser \& L. WANG, Voices from Tibet: Selected Essays and Reportage. Ed. \& tr. Violet S. Law: ix-xxxviii. Hong Kong: Hong Kong University Press.

Beebe, Maurice 1964. Ivory Towers and Sacred Founts: The Artist as Hero in Fiction from Goethe to Joyce. NY: NYU Press.

Bell, Sir Charles 1968. The People of Tibet. Oxford: OUP (first edn 1928).

BKRA SHIS DPAL LDAN 1999. rGyud skud steng gi rnam shes (Consciousness on Lute Strings). Beijing: Mi rigs dpe skrun khang.

BKRA SHIS DPAL LDAN 2006a. Phal pa'i khyim tshang gi skyid sdug (The Life of an Ordinary Family). Lhasa: Bod ljongs mi dmangs dpe skrun khang (first edn 1992).

BKRA SHIS DPAL LDAN 2006b. bDag dang bdag gi las skal dman pa'i mi sna dang skad yig (I and My Underprivileged Characters and Language). In: mTsho sngon bod yig gsar 'gyur khang (ed.), Nags klong khu byug 'du gnas (The Forest Abode of Cuckoos): 37-44. Beijing: Mi rigs dpe skrun khang.

BSE CHANG SANGS DON 2011. $<<$ SMug pa $>>$ nang gi mthong snang - tshe ring don grub kyi sgrung ring $<<$ smug pa $>>$ gleng ba (A Vision inside Fog - A Discussion of Tsering Dhondup's Novel Fog). In: CHAB BRAG MGon PO SKYABS (ed.): 179-190.

BTSUN PO DON 'GRUB 2014. Tshe ring don grub kyi sgrung gtam la dpyad pa (Examining Tsering Dhondup's Stories). Xining: mTsho sngon mi rigs dpe skrun khang.

BYAMS PA TSHUL KHRIMS 2011. Rig gnas gdong thug gis skrun pa'i gtam rgyud - brtsams sgrung ring gras $<<$ smug pa $>>$ yi sgyu rtsal rin thang la cung zad dpyad pa (A Story Based on Cultural Encounters - A Brief Examination on the Literary Value of the Novel Fog). In: Chab BRAG MGon Po SKYABS (ed.): 191-213.

Chab BRAG MGon Po SKYABS (ed.) 2011. Tshe ring don grub kyi rtsams sgrung zhib 'jug (The Research on Tsering Dhondup's Stories). Lanzhou: Kan su'u mi rigs dpe skrun khang.

Collinge, Ian 1993. The Dra-nyen (The Himalayan lute). Chime: Journal of the European Foundation for Chinese Music Research 6: 22-33. <https://docs.wixstatic.com/ugd/c191ef_0e47430a80be463398a91ccc5a176f8b.pdf>, accessed 13 Aug. 2018.

DAS, Sarat Chandra 1991. A Tibetan-English Dictionary. New Delhi: Gaurav Publishing House.

Don GRUB RGYAL 1981. 'Bol rtsom zhogs pa'i skya rengs (The Dawn of Clear Writing). Xining: mTsho sngon mi rigs dpe skrun khang.

DON GRUB RGYAL 1997. dPal don grub rgyal gyi gsung 'bum (The Collected Works of Dhondup Gyal), II: brTsams sgrung phyogs bsgrigs (The Collected Stories). Ed. Ban kho \& bKra rgyal. Beijing: Mi rigs dpe skrun khang.

Engelhardt, Isrun 2011. Reflections in The Tibet Mirror: News of the World 1937-1946. In: G. Tuttle (ed.), Mapping the Modern in Tibet: 205-264. Andiast: International Institute for Tibetan and Buddhist Studies.

ERHARD, Franz Xaver 2013. Remembering History in Amdo: Three Literary Accounts for the Years from 1956 to 1976. In: T. Takeuchi, K. Iwao, A. Nishida, S. Kumagai \& M. Yamamoto (eds.), Current Issues and Progress in Tibetan Studies: Proceedings of the Third International Seminar of Young Tibetologists. (Kobe City University of Foreign Studies Journal of Research Institute 51): 103-123. Kobe: Kobe City University of Foreign Studies.

ERHARD, Franz Xaver 2019. The Representation of Power and Hegemony in Contemporary Fiction from Amdo: Tsering Döndrub’s Novel Fog. In: U. Wallenböck, B. Horlemann, \& J. PtáčKová (eds), Mapping Amdo Dynamics of Power (Archív orientální: Supplementa XI): 221-240. Prague: Oriental Institute.

Fitzherbert, Solomon George 2010. A Modern Version of the Birth of Gesar. In: S. Arslan \& P. Schwieger (eds), Tibetan Studies: An Anthology. PIATS 2006: Tibetan Studies: Proceedings of the Eleventh Seminar of the International Association for Tibetan Studies, Königswinter 2006: 215-254. Andiast: IITBS, International Institute for Tibetan and Buddhist Studies.

FJeld, Heidi 2005. Commoners and Nobles: Hereditary Divisions in Tibet. Copenhagen: NIAS Press.

Gertzman, Jay A. 1989. A Descriptive Bibliography of Lady Chatterley's Lover, With Essays Toward a Publishing History of the Novel. NY: Greenwood Press.

Goldstern, Melvyn C. (ed.) 1975. Tibetan-English Dictionary of Modern Tibetan. Kathmandu: Ratna Pustak Bhandar. 
HARrIs, Clare 1999. In the Image of Tibet: Tibetan Painting after 1959. London: Reaktion Books.

Hartley, Lauran R. 2008. Heterodox Views and the New Orthodox Poems: Tibetan Writers in the Early and Mid-Twentieth Century. In: L.R. Hartley \& P. Schiaffini-Vedani (eds), Modern Tibetan Literature and Social Change: 3-31. Durham: Duke University Press.

Heimsath, Kabir Mansingh 2005. Untitled Identities: Contemporary Art in Lhasa, Tibet. asianart.com, 16 Dec. 2005. $<$ asianart.com/articles/heimsath/>, accessed 30 Apr. 2014.

Henrion-Dourcy, Isabelle 2017. Studying the Tibetan Performing Arts: A Bibliographic Introduction (1986-2017). In: I. Henrion-Dourcy (ed.), Studies in The Tibetan Performing Arts (Revue d'Etudes Tibétaines 40): 5-54. Paris: UMR 8155 (CRCAO) of the CNRS.

Herdan, Innes 1992. The Pen and the Sword: Literature and Revolution in Modern China. London: Zed Books.

HLAdíkovÁ, Kamila 2018. Literární cenzura a autocenzura v Číně: Dvě případové studie (Literary Censorship and Self-Censorship in China: Two Case Studies). World Literature Studies 10(4): 58-71.

Hosiaisluoma, Yrjö 2003. Kirjallisuuden sanakirja. Helsinki: WSOY.

Hsü, Immanuel C.Y. 1990. The Rise of Modern China. NY: OUP.

Hyde, H. Montgomery 1990. Introduction. In: The Lady Chatterley's Lover Trial: 1-48. London: The Bodley Head.

HYPÉn, Tarja-Liisa 1992. Juhani Ahon taiteilijat Kuopion torilla ja taiteen markkinoilla. In: T.-L. Hypén (ed.), Pakeneva keskipiste: Tutkielmia suomalaisesta taiteilijaromaanista (Taiteiden tutkimuksen laitos, Sarja A, No 26): 11-28. Turku: Turun yliopisto.

JABB, Lama 2015. Oral and Literary Continuities in Modern Tibetan Literature: The Inescapable Nation. Lanham: Lexington Books.

JABB, Lama 2019. The Wandering Voice of Tibet: Life and Songs of Dubhe. Life Writing. DOI: 10.1080/14484528.2019.1680247, accessed 16 Apr. 2020.

JoYCE, James 2016. A Portrait of the Artist as a Young Man. NY: Penguin Books.

LaWrenCE, D.H. 1937. Lady Chatterley's Lover. London: William Heinemann.

Lawrence, D.H. 1972. The First Lady Chatterley (The first version of 'Lady Chatterley's Lover'), with a Foreword by Frieda Lawrence. Heinemann: London.

LaZarus, Emma 1883. The New Colossus. Statue of Liberty: National Monument of New York. <nps.gov/stli/learn/ historyculture/colossus.htm>, accessed 27 May 2019.

LinK, Perry 2000. The Uses of Literature: Life in the Socialist Chinese Literary System. Princeton: PUP.

LoKke, Kari 2003. "Children of Liberty": Idealist Historiography in Staël, Shelley, and Sand. PMLA 118(3): 502-520.

LoKke, Kari 2004. Tracing Women's Romanticism: Gender, History and Transcendence. London: Routledge.

Lopez, Donald S., Jr 2013. Gendun Chopel: Tibet's First Modern Artist. NY: Trace Foundation's Latse Library in association with Serindia Publications.

Mao Tse-Tung 1962. Talks at the Yenan Forum on Literature and Art. 3rd edn. Peking: Foreign Languages Press.

Mathewson, Rufus W., Jr 1975. The Positive Hero in Russian Literature. 2nd edn. Stanford: SUP.

Miller Sangster, Leigh 2012. Memory and Cultural Sustainability in Contemporary Tibetan Art. Asia Art Archive: Ideas. February 2012, <https://aaa.org.hk/en/ideas/ideas/memory-and-cultural-sustainability-in-contemporarytibetan-art/type/essays>, accessed 29 July 2020.

Miller, Leigh 2016. The "Look of Tibet" Without Religion: A Case Study in Contemporary Tibetan Art in Lhasa. Himalaya: The Journal of the Association for Nepal and Himalayan Studies 36(1): 56-79.

Morcom, Anna 2007. Modernity, Power, and the Reconstruction of Dance in Post-1950s Tibet. Journal of the International Association of Tibetan Studies (JIATS) 3 (December): 1-42.

Morcom, Anna 2010. History, Traditions, Identities and Nationalism: Drawing and Redrawing the Musical Cultural Map of Tibet. In: S. Arslan \& P. Schwieger (eds), Tibetan Studies: An Anthology. PIATS 2006: Tibetan Studies: Proceedings of the Eleventh Seminar of the International Association for Tibetan Studies, Königswinter 2006: 385-417. Andiast: IITBS, International Institute for Tibetan and Buddhist Studies.

MTSHO SNGON BOD YIG GSAR 'GYUR KHANG (ed.) 2006. Nags klong khu byug 'du gnas (The Forest Abode of Cuckoos). Beijing: Mi rigs dpe skrun khang. 
OKAWA, Kensaku 2017. A Study on nang zan: On the Reality of the "Servant Worker" in Traditional Tibetan Society. In: F.X. Erhard, J. Bischoff, L. Doney, J. Heimbel \& E.R. Sulek (eds), Ancient Currents, New Traditions: Papers Presented at the Fourth International Seminar of Young Tibetologists: 278-292. Potsdam: Edition Tethys.

Phayul 2012. Gagged by China, Tibetan writers find voice in Norway. $<$ https://www.phayul.com/2012/08/30/32018/>, accessed 31 Aug. 2012.

Ramble, Charles 2019. The Tibetan Novel as Social History: Reflections on Trashi Palden's Phal pa'i khyim tshang gi skyid sdug. Revue d'Etudes Tibétaines 49: 149-191.

RANG GROL 1984. Sha dang rus pa'i brtse dungs (The Love of Flesh and Bone). sBrang char 2: 19-43.

Rhie, Marylin M. \& Robert A.F. Thurman 1991. Wisdom and Compassion: The Sacred Art of Tibet. Photographs by John Bigelow Taylor. San Francisco: Asian Art Museum and Tibet House, in association with Harry N. Abrams.

Rimmon-Kenan, Shlomith 1983. Narrative Fiction: Contemporary Poetics. London: Methuen.

Rin Chen Lha mo (Mrs Louis King) 1926. We Tibetans. London: Seeley Service \& Co. limited.

Samuel, Geoffrey 1996. The Gesar Epic of East Tibet. In: J.I. CABezón \& R.R. JAckson, Tibetan Literature: Studies in Genre: 358-367. Ithaca: Snow Lion.

SAND, George 1949. Taiteilijattaren tarina (Consuelo). Tr. into Finnish by Katri Ingman. Porvoo: WSOY.

Savolainen, Mari 2007. Dunglen Lute Music and the Beginning of Popular Music in Amdo. The Sixth Nordic Tibet Research Conference, May 5-6, 2007. <erg.su.se/om-oss/evenemang/konferenser/the-sixth-nordic-tibetresearch-conference-may-5-6-2007-1.38953>, accessed 14 Aug. 2012.

SHAKYA, Tsering 1999/2000. The Dragon in the Land of Snows: A History of Modern Tibet Since 1947. NY: Penguin Compass.

SHAKYA, Tsering 2000. The Waterfall and Fragrant Flowers: The Development of Tibetan Literature Since 1950. In: F. Stewart, H.J. Batt \& T. Shakya (eds), Song of the Snow Lion: Writing from Tibet (Mānoa 12(2)): $28-40$. Honolulu: University of Hawai'i Press.

Shakya, Tsering 2004. The Emergence of Modern Tibetan Literature - gsar rtsom. PhD dissertation, School of Oriental and African Studies (University of London). EThOS.

SHAKYA, Tsering 2018. The Joys and Sorrow of an Ordinary Family: A Study of Tibetan Novel. In: P.L. GroKHOVSKIY (ed.), Modernizing the Tibetan Literary Tradition: 42-61. St Petersburg: St Petersburg University Press.

Sмiтн, Warren W., Jr 1997. Tibetan Nation: A History of Tibetan Nationalism and Sino-Tibetan Relations. New Delhi: Harper Collins Publishers India.

Sonam Tashi \& Eric Henningsen 2010. Acho Namgyal: Shey kyi jinpa (An Ion Digital Film, Sonam Tashi Production). $<$ youtube.com/watch?v=f4r9W8QB928>, accessed 13 May 2019.

SteIN, R.A. 1972. Tibetan Civilization. Tr. J.E. Stapleton Driver. Stanford: SUP.

Stoddard, Heather 1994. Don grub rgyal (1953-1985): Suicide of a Modern Tibetan Writer and Scholar. In: P. Kvaerne (ed.), Tibetan Studies: Proceedings of the 6th Seminar of the International Association for Tibetan Studies, Fagernes 1992: 825-836. Oslo: The Institute for Comparative Research in Human Culture.

Sørensen, Per K. \& Franz Xaver Erhard 2013. Tibetan Proverbial Literature: Semantics and Metaphoricity in Context. In: F.-K. Ehrhard \& P. Maurer (eds), Nepalica-Tibetica: Festgabe für Christoph Cüppers: 237-251. Andiast: IITBS, International Institute for Tibetan and Buddhist Studies.

Su Wei 2000. The School and the Hospital: On the Logics of Socialist Realism. In: P.-Y. Chi \& D. Der-wei Wang (eds.), Chinese Literature in the Second Half of a Modern Century: 65-75. Bloomington: IU Press.

ThöNDRUPGYäL 2007. L'Artiste tibétain. Tr. into French by Françoise Robin. Paris: Bleu de Chine.

TSEPAK Rigzin 1997. Tibetan-English Dictionary of Buddhist Terminology (Revised and Enlarged Edition). Dharamsala: Library of Tibetan Works and Archives.

Tsering Woeser 2013. gSar brje (Forbidden Memory: Tibet During The Cultural Revolution). Photos by Tsering Dorjee. Tr. into Tibetan by Dolkar. Tibetan e-book. Lotus Seeds Design.

TSHE RING DON GRUB 2002. sMug pa (Fog). Xining: Zhang kang gyi ling dpe skrun khang.

TSHE RING DON GRUB 2006. Nga rang shes med tshor med ngang nas gsar rtsom las la zhugs (I started writing before I realized). In: mTsho sngon bod yig gsar 'gyur khang (ed.), Nags klong khu byug 'du gnas. Beijing: Mi rigs dpe skrun khang.

Wang, David Der-wei 2000a. Introduction. In: P.-Y. CHI \& D. Der-wei WANG (eds), Chinese Literature in the Second Half of a Modern Century: xiii-xliii. Bloomington: IU Press. 
Wang, David Der-wei 2000b. Reinventing National History: Communist and Anti-Communist Fiction of the Mid-Twentieth Century. In: P.-Y. CHI \& D. Der-wei WANG (eds) Chinese Literature in the Second Half of a Modern Century: 39-64. Bloomington: IU Press.

Waves on the Turquoise Lake: Contemporary Expressions of Tibetan Art 2007. An exhibition and symposium curated by Lisa Tamiris Becker and Tamar Victoria Scoggin. CU Art Museum / University of Colorado at Boulder.

Weiner, Benno Ryan 2012. Chinese Revolution on the Tibetan Frontier: State Building, National Integration and Socialist Transformation, Zeku (Tsékhog) County, 1935-1958. PhD dissertation, Columbia University. <academiccommons.columbia.edu/catalog/ac:153343>, accessed 10 Sept. 2012.

Virtanen, Riika J. 2000. Introduction. In: R.J. Virtanen (compl. and tr.), A Blighted Flower and Other Stories: Portraits of Women in Modern Tibetan Literature: 11-30. Dharamsala: LTWA.

Virtanen, Riika J. 2014. Tibetan Written Images: A Study of Imagery in the Writings of Dhondup Gyal. (Studia Orientalia 115) Helsinki: Finnish Oriental Society.

Virtanen, Riika J. 2016. Characters in Modern Tibetan Fiction Set in Pre-1950s Central Tibet: Aristocrats, Common Folk and Others. Revue d'Etudes Tibétaines 37: 490-514.

VIRTANEN, Riika J. 2018. Ordinary Heroes and Heroines? - Fictional Stories of Tibetans and Life in the Countryside in the gTsang and A mdo Regions. Himalayan Discoveries 2(1): 59-94.

Yangdon Dhondup 2002. Writers at the Cross-roads: The Mongolian-Tibetan Authors Tsering Dondup and Jangbu. Inner Asia 4: 225-240.

Yangdon Dhondup 2008. Roar of the Snow Lion: Tibetan Poetry in Chinese. In: L.R. Hartley \& P. SchiaffiniVedani (eds), Modern Tibetan Literature and Social Change: 32-60. Durham: Duke University Press. 